\title{
Milan Radošević
}

Zavod za povijesne i društvene znanosti HAZU u Rijeci, Područna jedinica u Puli

Prolaz kod kazališta 2, HR-52100 Pula

mrados@hazu.hr

\section{Palež pulskoga Narodnog doma 14. VII. 1920. ili kako je otvorena fašistička Pandorina kutija*}

\author{
Izvorni znanstveni rad | Original scientific paper \\ UDK 329..18:<374.72:616.89-008.444.8>](497.57Pula)"1920" \\ DOI 10.32728/h2020.04 \\ Primljeno | Received: 31. VIII. 2020.
}

\begin{abstract}
Izvadak
Znameniti talijanski povjesničar Renzo de Felice za epizodu fašističkoga paljenja Narodnoga doma u Trstu 13. VII. 1920. naveo je da predstavlja istinsko krštenje fašističkih skvadri. Istovremeno, pulski slučaj koji se zbio narednoga dana paljenjem Narodnoga doma u Carrarinoj ulici ostao je na marginama (hrvatske) historiografije. U ovome će se radu kroz analizu arhivskoga gradiva (Središnjega državnoga arhiva u Rimu, Arhiva talijanskoga parlamenta, Hrvatskoga državnog arhiva u Zagrebu, Državnoga arhiva u Pazinu) i periodike (Naša sloga, ll Gazzettino di Pola, Hrvatski list, L'Azione, Il Proletario, Il Lavoratore, Il Popolo d'Italia, Corriere della Sera i dr.), nakon kraćega povijesnog pregleda djelatnosti pulskoga Narodnog doma, nastojati rekonstruirati uzroke, tijek i posljedice fašističkoga napada na tu ustanovu (14. VII. 1920.) te napada na odvjetničke urede Mirka Vratovića i Ive Zuccona (15./16. VII. 1920.).
\end{abstract}

\section{Excerpt}

The eminent Italian historian Renzo de Felice stated that the episode of the fascist arson of the People's Hall in Trieste on 13 July 1920 represented the true baptism of fascist squads. At the same time, the Pula incident, taking place the next day with the arson of the People's Hall in Carrara Street, remained on the margins of (Croatian) historiography. Through the analysis the archives (Central Archives of the State in Rome, the Italian Parliamentary Archives, the Croatian State Archives in Zagreb, the State Archives in Pazin) and periodicals (Naša sloga, Il Gazzettino di Pola, Hrvatski list, L'Azione, Il Proletario, Il Lavoratore, Il Popolo d'Italia, Corriere della Sera, etc.), and after a brief historical overview of the activities of the People's Hall in Pula, his

Istraživanje je dijelom financijski podržala Istarska županija kroz program Istarskoga povijesnog društva „Stoljeće europskog antifašizma - Istra izmeđ u lokalnog i globalnog“" te Talijanska nacionalna akademija (Accademia Nazionale dei Linceı) istraživačkom stipendijom u sklopu suradnje s Hrvatskom akademijom znanosti i umjetnosti. 
paper is going to try to reconstruct the causes, the course itself and the consequences of the fascist attack on that institution (14 July 1920) and the attacks on the law firm offices of Mirko Vratović and Ivo Zuccon (15/16 July 1920).

Ključne riječi: fašizam, Istra, Pula, Narodni dom, Giovanni Oriolo, Luigi Bilucaglia, Mirko Vratović, Ivo Zuccon, Ivan Cukon

Key words: fascism, Istria, Pula, National Hall, Giovanni Oriolo, Luigi Bilucaglia, Mirko Vratović, Ivo Zuccon, Ivan Cukon

\section{Uvod}

Nakon završetka Velikoga rata i primirja između Kraljevine Italije i AustroUgarske Monarhije sklopljenoga u Villi Giusti 3. XI. 1918. istarski je poluotok okupirala talijanska vojska. U Puli su talijanske snage preuzele vlast od Mjesnoga odbora SHS 5. XI. 1918., a do kraja godine zapovjednik Pomorske utvrde Pula admiral Umberto Cagni donio je niz zapovijedi koje su odredile, između ostaloga, da grad moraju napustiti oni koji nemaju pravo zavičajnosti, da su štrajkovi zabranjeni, ali i da se određene hrvatske institucije koje su djelovale za bivše austrijske vlasti, poput mjesnih čitaonica na Puljštini, imaju zatvoriti. ${ }^{1}$ Tijekom dvije godine okupacije, zaključno s Rapalskim ugovorom od 12. XI. 1920., temeljem kojega Istra službeno postaje dijelom Kraljevine Italije, na tom su se prostoru odvijali politički procesi koji će pogodovati razvoju fašističkoga pokreta.

Iako se prvi Fascio di Combattimento osniva u Rovinju već 1919., ${ }^{2}$ tek će s prvom polovicom 1920., nakon povratka istarskih legionara iz Rijeke, fašistički jurišni odredi (squadre d'azione) početi organizacijske pripreme za dolazak na veliku pozornicu uz (ne)skrivene simpatije vojnih i policijskih snaga. ${ }^{3}$ Tzv. „pogranični fašizam“ (fascismo di frontiera) ${ }^{4}$ u tom razdoblju u okupiranoj Julijskoj krajini postaje nositelj talijanskih nacionalnih interesa ne

1 Dragovan Šepić, „Istra uoči konferencije mira. Talijanska okupacija Istre 1918. i istarski Hrvati“, u: Hrvatski pokret u Istri, Račice 2004., 527, 536.

2 Diego Han, „Rovigno dalla fine della Grande Guerra all'instaurazione della dittatura fascista (1919-1926)“, Quaderni, 27, 2016., 257, 260-261.

3 Darko Dukovski, Fašizam u Istri, Pula 1998., 49-52.

4. Na tu temu vidi više u: Annamaria Vinci, Sentinelle della patria. Il fascismo al confine orientale 1918-1941, Roma - Bari 2011., 272; Marco Bresciani, „, The Post-Imperial Space of the Upper Adriatic and the Post-War Ascent of Fascism“, Akteure der Neuordnung. Ostmitteleuropa und das Erbe der Imperien, 1917-1924, Hg. Tim Buchen und Frank Grelka, Frankfurt/Oder 2016., 47-64; isti, „Lost in Transition? Habsburg Legacies, state- and Nation-Building and the new fascist order in the Upper Adriatic", National Indifference and the History of Nationalism in Modern Europe, edited by Maarten Van Ginderachter and Jon Fox, London - New York 2019., 56-80. 
libeći se rabiti sva sredstva u borbi protiv dva arhetipska neprijatelja fašizma - socijalističkoga pokreta te hrvatskoga i slovenskoga nacionalno-političkoga korpusa. Četiri su neuralgične točke, četiri događaja vezana za 1920. koji su, naravno ne bez utjecaja egzogenih čimbenika, usmjerili dinamiku geneze (anti)fašizma u Istri. Radi se o: (1) „Vodnjanskoj bitci“ 16. I. 1920., u kojoj se po prvi put lokalni fašisti uz prisutnost karabinjera i vojnika usuđuju fizički razračunati s neistomišljenicima, uhićenim civilima Kluba za društvene studije (Circolo di Studi Sociali); (2) prvomajskim „krvavim demonstracijama“ i sukobu prosvjednika s karabinjerima u Puli, u kojima su nerazjašnjenu ulogu imali fašisti; (3) fašističkom paljenju Narodnoga doma u Puli i demoliranju odvjetničkoga ureda Ive Zuccona (Ivana Cukona) te nasilnom upadu u ured Mirka Vratovića 14. - 16. VII. 1920. te (4) dolasku Benita Mussolinija u Pulu 21. IX. 1920. i sukobu fašista i socijalista. U tim je zbivanjima (osim srpanjskoga slučaja) stradalo više civila (dominantno socijalističkoga usmjerenja) te jedan karabinjer.

Nadalje, izuzev donekle „Vodnjanske bitke“, ${ }^{5}$ ostale su „epizode“ ostale na marginama istarske i hrvatske historiografije, ${ }^{6}$ bitno zaostajući za rezultatima srodnih istraživanja za područje Trsta i okolice u susjednih historiografija sjevernojadranskoga područja. Primjer tomu je i pristup istraživanju, količina objavljenih znanstvenih radova i dokumenata na temu Narodnoga doma u Trstu od njegovih početaka 1904. zaključno s fašističkim paljenjem zdanja (13. VII. 1920.), ${ }^{7}$ ali, jednako važno, i muzejska aktivnost koja nastoji sačuvati od zaborava važan segment kulturno-političke povijesti tršćanskih Slovenaca, ali

5 Vrijedan prinos na temu dao je prije pola stoljeća talijanski književnik i publicist Giacomo Scotti radom „Gennaio 1920: Lo sciopero di Pola e la 'Battaglia di Dignano'“, Quaderni, 1, 1971., 191-224. Navest ćemo i novu studiju autora ovoga članka „Vodnjanska bitka 16. I. 1920. i fašizam u Istri: početak“, Problemi sjevernog Jadrana, 19 (u tisku).

6 Kraći publicističko-povijesni osvrt na paljenje Narodnoga doma u Puli u okviru promišljanja o „crvenome dvogodištu“ na Puljštini 1920. - 1921. objavljen je u tekstu Bruna Flega i Ottavija Paoletića „Il «biennio rosso» a Pola e nel circondiario. Gli avvenimenti nel 1920-1921“, Quaderni, 8, 1984-1985., 41-68.

7 Izdvojit ćemo: „Slovenske premiere v Trstu od ustanovitve Dramatičnega društva do požiga Narodnega doma (1902-1920)“, Dokumenti Slovenskega gledališkega muzeja, 1, 4, 1965., 146-153; Elio Apih, Italia, fascismo e antifascismo nella Venezia Giulia (1918-1943), Roma - Bari 1966., 121-127; Lavo Čermelj, „Ob petdesetletnici požiga Narodnega doma v Trstu“, Kronika, 18, 2, 1970., 97-104; Marko Kravos i dr., Narodni dom v Trstu 1904-1920, Devin 1995., 134; Milan Pahor, ,»Zrno do zrna, pogača, kamen do kamna, palača! « Društvo »Narodni dom v Trstu« 1900-2000“, Zgodovinski časopis, 53, 2, 1999., 325-350; Milica Wohinz, „L'incendio del 'Narodni Dom' a Trieste“ (dalje: „L'incendio“), Qualestoria, 28, 1, 2000., 89-100; Narodni dom-Balkan: izvirni dokumenti ob 80-letnici požiga, ur. Erik Dolhar i Marko Korosi, Ljubljana 2000., 123; Marina Cattaruzza, L'Italia e il confine orientale, 1866-2006 (dalje: L'Italia e il confine orientale), Bologna 2007., 142-144; Almerigo Apollonio, Dagli Asburgo a Mussolini. Venezia Giulia 1918-1922 (dalje: Dagli Asburgo a Mussolini), Trieste 2001., 291-302; Matteo Di Figlia, „Dimenticare il «Balkan». La distruzione del Narodni Dom di Trieste nelle rielaborazioni fasciste (1921-1941)“, Qualestoria, 44, 2, 2016., 7-23; Martina Wohinz - Ace Mermolja, Narodni dom: Trst 1904-1920: spominske poti Slovencev v Trstu, Trst 2020., 79. U tisku je (za 2021.) i znanstvena monografija Ogenj, ki je zajel Evropo. Narodni dom v Trstu 1920 - 2020. slovenskih povjesničara Gorazda Bajca i Boruta Klabjana. 
i Tršćana općenito. ${ }^{8}$ Više je razloga tomu. Tršćanski slučaj zbio se dan prije pulskoga pa je time, ali i zbog činjenice da je u neredima smrtno stradao jedan časnik te dva civila, „ukrao“ pozornost talijanskih i slovenskih istraživača koji usto žive na tome području ili mu istraživački gravitiraju. Osim toga, Dom u Trstu tek je 2020. vraćen u vlasništvo slovenskoj nacionalnoj manjini, dok je drugačiju sudbinu imao pulski Dom, našavši se na teritoriju koji je 1947. službeno pripojen Jugoslaviji. Naposljetku, i u povijesnom aspektu tamošnji fašistički pokret bio je, počevši od 1919., nesumnjivo brojniji i organiziraniji, što je imalo stanovite geostrateške implikacije uzimajući u obzir položaj, ali i značaj Trsta kao najvećega grada regije. Neovisno o tome, nesrazmjerna je pozornost koju je (u pozitivnom pogledu) slovenska i talijanska historiografija posvetila paljenju Hotela Balkan spram hrvatske historiografije paljenju Doma u Puli. ${ }^{9}$ Tu nam tezu možda najbolje ilustrira podatak da na „mjestu zločina“, pročelju zgrade na pulskoj adresi u Carrarinoj ulici br. 5, današnjem sjedištu podružnice Hrvatske gospodarske komore, i dalje stoji spomen ploča postavljena 1962., koja navodi netočan datum paljenja Doma - 13. VII. 1920. godine (slika 1).

U tom kontekstu cilj je ovoga rada pokušati rekonstruirati društvenopolitičke okolnosti koje su omogućile napad i uništenje zgrade Narodnoga doma u Puli te provalu u stanove hrvatskih odvjetnika, ustanoviti kakva je uloga bila fašista, a kakva talijanske okupacijske vojske i karabinjera te kakve su pravne posljedice poduzete po počinitelje. S ciljem boljega razumijevanja važnosti Doma za kulturu i političku homogenizaciju pulskih Hrvata, čime je postao meta talijanskih nacionalista-fašista, pružit će se kraći povijesni pregled aktivnosti koje su se u njemu odvijale od samih početaka (1906.) do nacionalizacije i prenamjene u fašističke svrhe (početkom 30-ih godina 20. stoljeća).

\section{Svrha i aktivnosti Narodnoga doma u Puli te prvi napad na nj (1906. - 1914.)}

Do izbijanja Velikoga rata središnju kulturnu ustanovu Hrvata, ali i Slavena Puljštine uopće, predstavljao je Narodni dom. Izgrađen potkraj 1906. nedaleko od Dvojnih vrata, na adresi Viale Carrara 5, okupljao je gospodarske i kulturne ustanove pretežito hrvatskoga predznaka. U velebnom četveroe-

8 Godine 2016. u tršćanskome je Domu postavljen trajni postav izložbe, koju je moguće pregledati na mrežnoj stranici http://www.narodnidom.eu.

9 Povijesna istraživanja djelokruga Narodnoga doma u Puli do danas su se ograničila uglavnom na aspekt djelatnosti Hrvatske čitaonice i Javne pučke knjižnice, koje su ondje imale sjedište. Bruno Dobrić, „Udruga Čitaonica u Puli (1869. - 1920.)“(dalje: „Udruga Čitaonica“), u: Spomen-knjiga prigodom 125. obljetnice osnutka udruge Čitaonica u Puli, Pula 1998., 25-32, 85-111; Josip Stipanov, Povijest knjižnica i knjižničarstva u Hrvatskoj (dalje: Povijest knjižnica), Zagreb 2015., 139-151. 
tažnom zdanju (slika 2) nakon otvaranja 2. XII. 1906. sjedište je pronašla kreditna zadruga Istarska posujilnica (na prvome katu), koja je ujedno bila i vlasnikom čitave zgrade. Prvi je kat s Posujilnicom od početaka „dijelila“i Hrvatska čitaonica (objema ustanovama bio je na čelu Matko Laginja), koja je imala svoju dvoranu te Gospodarska sveza (savez) za Istru. U prizemlju je objekta, pak, s lijeve strane, svoja vrata Puljanima otvorila „Gostiona i kavana Narodni dom“ s pripadajućim vrtom, vlasnika Grge Basletića. Središnji dio prizemlja činila je velika, svečana dvorana kojom se koristio za razne zabave i kulturna događanja Prvi istarski sokol. U Domu od studenoga 1907. nalazimo i pulsku podružnicu Narodne radničke organizacije u Trstu. U narednom razdoblju u prizemlje se (s desne strane od ulaza) uselila i „Građanska plzenska pivovara“. Prostorije na drugome i trećem katu te u potkrovlju bile su namijenjene za stanovanje, odnosno odvjetničke urede. ${ }^{10}$

Zanimljivost predstavlja podatak objavljen u Našoj slogi da je odvjetnik Ivo Zuccon već 15. X. 1906. - prije službenoga otvaranja Narodnoga doma - ondje otvorio svoj ured. Možda je upravo on bio i prvi stanar novoga zdanja. U njemu djeluje do ljeta 1910., kada (1. VIII.) otvara odvjetnički ured u Poreču. Drugi istaknuti hrvatski odvjetnik, Lovro Škaljer (Scalier), djelovao je i živio u Narodnome domu od veljače 1913. do odlaska iz Pule studenoga 1918. godine. ${ }^{11}$

Važan događaj u pogledu afirmacije Narodnoga doma u kulturnome životu Pule zbio se 1909., kada se spajanjem knjižnica Hrvatske čitaonice, Narodne radničke organizacije i Sokola osniva Javna pučka knjižnica. Njome su, za razliku od postojeće talijanske knjižnice Biblioteca civica koju su financirale gradske vlasti, upravljala hrvatska društva. Korištenje javne knjižnice bilo

10 Gradnja Narodnoga doma započela je 26. VI. 1905. Tom je prilikom tjednik Naša sloga pisao: „U ponedjeljak su napokon nakon toliko prekapanja i pregovaranja odpočele radnje za Narodni Dom u Puli. Radnju će voditi uprava Istarske Posujilnice, koja je vlastnik Doma, a upravljat će radnjama ovlašteni graditelj g. Dorigo. Zgrada će se nalaziti u ulici Carrara, na krasnom položaju, u središtu grada, te će biti na tri kata. U zgradi će se nalaziti krasna i prostrana dvorana sa galerijom i stalnom pozornicom, te će biti jedna od najljepših u Puli. S veseljem pozdravljamo započeto djelo sa željom, da bude sretno i brzo dokončano, da iz tog narodnog hrama uzmognu što prije vrcati iskre hrvatske prosvjete i rodoljubne sviesti.“ Službeno otvorenje zgrade dogodilo se istodobno kada i useljenje Istarske posujilnice u nove prostore, 2. XII. 1906. Gostionica i kavana G. Basletića počela je s radom oko Božića iste godine. „Narodni Dom u Puli“, Naša sloga, 26, 29. VI. 1905., 2; „Otvorenje 'Narodnog Doma’ u Puli“, isto, 49, 6. XII. 1906., 3, „Silvestrova večer“, isto, 52, 27. XII. 1906., 1; „Gostiona i kavana u Narodnom domu“, isto, 1, 3. I. 1907., 1; „Izborna skupština“, isto, br. 28, 28. II. 1907., 2; „Jedna zabrana u Puli“, isto, 2, 9. I. 1913., 2; „Istarski Sokol u Puli“, Istra, 7, 20. VII. 1930., 3-4; Branko Perović, Austrougarske vile i kuće u Puli, Pula 2010., 72-73.

11 U Narodnome domu početkom svibnja 1911. bilježnički ured otvara i Ivan Šorli. „Odvjetnik dr. Ivo Zuccon“, Naša sloga, 42, 18. X. 1906., 4; „Dr. Ivo Zuccon“, Omnibus, 1198, 2. VIII. 1910., 1; „Dr. I. Šorli“, Naša sloga, 19, 11. V. 1911., 4; „Odvjetnik dr. Lovro Scalier otvorio je svoju pisarnu u Puli“, isto, 8, 20. II. 1913., 4; „Vojnički kazneni branitelj dr. Lovro Scalier“, isto, 49, 17. XII. 1914., 4; „Naši na Krfu“, Hrvatski list, 1198 , 9. XI. 1918., 2. 
je besplatno, otvoreno svima, ${ }^{12}$ a time i pristupačnije široj čitateljskoj publici, ponajprije Hrvatima i drugim slavenskim narodima Pule. Svojim djelovanjem i širenjem „kulture čitanja“ Čitaonica, a kasnije i Knjižnica, opovrgavale su stav talijanskoga liberalnoga građanskog kruga u Istri koji se povodio stavom da će pripadnici hrvatskoga i slovenskoga etnikuma biti dobrovoljno asimilirani i inkorporirani u talijansku, civilizacijski superiorniju naciju. ${ }^{13}$

Iz navedenoga je razvidno da je Narodni dom bio simbolom, ali ujedno i „krovnom kućom“ važnijih hrvatskih i slavenskih gospodarskih i kulturnih udruženja, ustanova i odvjetničkih ureda, mjesto druženja, zabave, ali, valja zaključiti, i centar političkih razgovora hrvatskih prvaka. Shodno tome talijanski iredentisti, među kojima se isticao Ruggero Timeus (pseudonimom Ruggero Fauro), u narodnim domovima Austrijskoga primorja - izgrađenima u Trstu 1904., ali, primjerice, iste godine kada u Puli i u manjim mjestima Pazinu, Roču, Velom Lošinju ${ }^{14}$ - vidjeli su simbole neprijateljskoga, hrvatskoga kulturnoga, u konačnici nacionalnoga uzdizanja. ${ }^{15}$ Negodovanja su bila prisutna i među talijanskim političarima u Istri: u govoru na sastanku delegacija zemaljskih parlamenata Austro-Ugarske Monarhije, zastupnik talijanske građanske liberalne stranke u Carevinskome vijeću Matteo Bartoli izjavio je 1911. da je „pulski Narodni dom mjesto sastajanja hrvatske stranke gdje se planiraju svi prosvjedi protiv Talijana pa i oni najbrutalniji“. ${ }^{16}$

Lapidaran primjer hrvatsko-talijanskoga političkog antagonizma u Puli možemo prikazati i kroz akt o zabrani posjeta kavani i gostionici Narodnoga doma pripadnicima kopnene vojske i mornarice početkom 1913. godine. Talijanski građansko-liberalni dnevnik Il Giornaletto di Pola-kojemu je

12 Na tu je temu pulski dnevnik Omnibus pisao: „Da je potreba jedne pučke knjižnice, o tome mislimo, da će biti svi uvjereni. Istina naša družtva imadu svoje knjižnice kao 'Sokol' i 'Narodna radnička organizacija', no te su samo za članove i osim toga, buduć ta družtva imadu drugu svrhu kao glavnu, a izobrazbu članova samo kao nuzgrednu, to te knjižnice ne mogu da udovolje dovoljno svojoj svrsi. Kod nas u Istri osniva pučke knjižnice u obilnoj mjeri 'Lega Nazionale', dapače i družtvo 'Dante Alighieri'. S naše strane se je u tom pogledu veoma malo uradilo.“ „Obća pučka knjižnica u Puli“, Omnibus, 1090, 1. III. 1909., 1.

13 Dobrić, „Udruga Čitaonica“, 29-31; Stipanov, Povijest knjižnica, 144-146.

14 „Narodni dom u Pazinu“, Naša sloga, 11, 15. III. 1906., 3; „Veliki Lošinj“, isto, 39, 27. IX. 1906., 2; „Otvorenje Narodnog doma u Roču“, isto, 45, 8. XI. 1906, 3.; „Na koncu godine“, isto, 52, 27. XII. 1906, 1.

15 U knjizi o Trstu, Istri i austrijskoj politici, Timeus ustanovu/pojam Narodnoga doma opisuje na sljedeći način: „naziv Narodni dom želi reći nacionalni dom. Upravo on predstavlja sjedište za slavenske organizacije koje vode nacionalnu borbu u gradovima. Narodni dom postoji u svim mjestima gdje se vodi slavenska borba; uvijek nalikuje tvrđavi u neprijateljskoj državi; uvijek stoji pravo bogatstvo, koje Slaveni iz pojedinih mjesta sigurno nisu mogli namaknuti, već novčana sredstva dolaze iz Hrvatske, Češke pa čak i iz Rusije.“ Ruggero Fauro, Trieste, Roma 1914., 122-123; Raffaele Molinelli, „Nazionalisti cattolici e liberali“, Rassegna storica del risorgimento, 52, 3, 1965., 375.

16 „Il discorso tenuto dall’ On. Bartoli nella seduta plenaria della Delegazione a. al 1 marzo“, Il Giornaletto di Pola, 3889, 4. III. 1911., 1; Bruno Dobrić, „Jedna od prvih fašističkih lomača knjiga u Europi. Spaljivanje Narodnoga doma s hrvatskom knjižnicom 1920. u Puli“, Nova Istra, 67, 2020., 21. 
Naša sloga „prišila“ epitet „organ kamorre“ - tu je odluku trijumfalno popratio člankom pod naslovom „Napokon“ („Finalmente“): „Tek su bučni iskazi panslavizma u Narodnom domu tijekom novogodišnje noći uspjeli protresti organe vlasti iz letargije koju su pokazivali kada je bila riječ o Slavenima te ih potaknuti da o tome što se događa u hrvatskoj kući obavijeste vojne vlasti koje su znale provesti prije spomenute mjere (zabrane, op. M. R.) (...). Organi vlasti ne mogu ignorirati vatrene govore koji se u tim prostorima drže ne samo protiv nas Talijana nego i protiv Ugarske (...). Naposljetku, posve je poznato da je hrvatska kuća nastala s ciljem da postane sjedištem slavenske agitacije (...) koja trenutno poprima delikatan politički karakter u odnosu spram posebnih interesa Monarhije i slavenskih država s kojima graniči“."

Tenzije između politički dominantnih stranaka Poluotoka - Talijanske nacionalno liberalne i Hrvatsko-slovenske narodne stranke - postajale su u godinama pred Prvi svjetski rat sve izraženije, a ratni sukob otvorio je mogućnost potpunoga ostvarenja njihovih nacionalnih težnji. ${ }^{18}$ Pulski će iredentisti, koji su činili manjinu pulskih Talijana, nakon atentata na austro-ugarskoga prijestolonasljednika u Sarajevu 28. VI. 1914. kamenjem napasti Narodni dom, razbiti natpis odvjetnika Matka Laginje i polomiti stakla hrvatske tiskare. Ipak, vojska će spriječiti daljnje nerede. ${ }^{19}$ Promjena političkih odnosa svega četiri godine poslije pokazat će da se radilo tek o odgodi materijaliziranja njihovih rušilačkih nacionalističkih nastojanja.

\section{Odnos talijanskih okupacijskih vlasti spram hrvatskih kulturnih ustanova u Puli}

Tijekom Velikoga rata Gradska knjižnica (Biblioteca civica) bila je zatvorena, ${ }^{20}$ a rad je Javne pučke knjižnice i Čitaonice u Narodnome domu, uslijed evakuacije civila 1915., utihnuo. Basletićeva kavana i dalje je radila, kao i ured dr. Škaljera. ${ }^{21}$ U prostorima Doma održavala se u školskoj 1917./1918. godini i

17 „Finalmente“, Il Giornaletto di Pola, 4561, 4. I. 1913., 1; „Jedna zabrana u Puli“, Naša sloga, 2, 9. I. 1913., 2.

18 Dragovan Šepić, „Povijest istarskih Hrvata od 1870. do 1914. godine“, u: Hrvatski pokret u Istri, Račice 2004., 88 .

19 „Bezdušnici - rulja tepista“, Naša sloga, 29, 30. VI. 1914., 2.

20 „Per la riapertura della Biblioteca civica“, Il Giornaletto di Pola, 954, 16. V. 1918., 2.

21 Godine 1917. u više je navrata u Hrvatskom listu objavljen oglas koji navodi: „Svoj k svome! Kavana Narodni dom opskrbljena je svim hrvatskim, slovenskim, češkim kao i drugim novinama raznih jezika. Na raspolaganje biljari i druge igre.“ „Kavana 'Narodni dom”“, Hrvatski list, 631, 4. IV. 1917., 3; „Hrvatska Čitaonica“, isto, 662, 5. V. 1917., 4; „Istarska posujilnica u Puli“, isto, 350, 28. VI. 1917., 2; „Pikantan list u prkos cenzuri“, isto, 944, 21. II. 1918., 3; „Za narodnu koncentraciju i organizaciju“, isto, 1117, 20. VIII. 1918., 1; „Konobarica ili naučnik“, isto, 1144, 25. VIII. 1918., 2. O evakuaciji civila Puljštine svibnja 1915. više u: Davor Mandić, Istra u vihoru Velikog rata, Pula 2013., 43-77. 
nastava za hrvatsku djecu koja su se tada postupno vraćala kući. ${ }^{22}$ Da je Dom ostao okupljalište pulskih politički upućenijih Hrvata - u ratnim okolnostima i širih slojeva - ukazuje i činjenica da su se početkom ljeta 1918. upravo u prostorijama tamošnje Čitaonice okupili roditelji i održali skupštinu u povodu rasprave o slanju njihove djece na „prehranu“ u tadašnju Hrvatsku i Slavoniju. ${ }^{23}$

Posljednje godine rata, nakon osnivanja Narodnoga vijeća (sveta) za Sloveniju, Istru i Dalmaciju u Ljubljani (16. VIII. 1918.) u istarskom hrvatskom tisku javljaju se inicijative za ponovnim oživljavanjem Čitaonice (Knjižnice) i drugih pulskih hrvatskih društava. Nedugo potom, 28. X. 1918., upravo je u Narodnome domu osnovan pulski Mjesni odbor Narodnoga vijeća Slovenaca, Hrvata i Srba. Za predsjednika je izabran Lovro Škaljer, a za dopredsjednika Mirko Vratović. ${ }^{24}$ Odbor je, sporazumno s odborom pulskih Talijana (osnovanim 29. X.), 30. X. preuzeo političku upravu u gradu, koja će djelovati tek do 5. XI. 1918. i ulaska talijanske vojske u Pulu. ${ }^{25}$

Talijanskom okupacijom Istre započinje represivna politika prema hrvatskom školstvu i kulturi u cjelini. Poručnik Sem Benelli, šef policijsko-obavještajne službe Pomorske utvrde u Puli (Piazza Forte di Pola) već 14. XI. 1918. u svome izvješću pulskom vojnom zapovjedništvu navodi da u krajevima gdje žive Slaveni ima mnogo skrivenoga oružja, a između ostaloga ono se nalazi i u pulskom Narodnome domu. ${ }^{26}$ Nadalje, Benelli je zapovjedniku Pomorske utvrde, admiralu Umbertu Cagniju, 13. XII. predložio zatvaranje „malih narodnih domova - čitaonica“ na Puljštini, ocjenjujući ih kao protutalijanska uporišta mladih jugoslavenskih zanesenjaka. Cagni je tri dana poslije potpisao zapovijed o njihovu raspuštanju, ${ }^{27}$ a slična situacija bila je i u ostatku Istre. ${ }^{28}$

22 U Narodnom domu održavala se nastava od rujna 1917. do travnja 1918., kada se otvara hrvatska škola u dotadašnjoj talijanskoj građanskoj školi u ulici Cenide. „Hrvatska škola u 'Narodnom domu““, Hrvatski list, 785, 15. IX. 1917., 3; „Hrvatska škola u Puli“, isto, 936, 13. II. 1918., 2; „Hrvatska škola u Puli“, isto, 974, 23. III. 1918., 2; „Pitanje hrvatskih škola u Puli“, isto, 1009, 4. V. 1918., 2.

23 „Putovanje naše djece u Hrvatsku i Slavoniju“, isto, 1058, 22. VI. 1918., 2.

24 „Ustanovna skupština mesnog odbora Narodnoga veća za Pulu“, isto, 1137, 29. X. 1918., 1.

25 Dragovan Šepić, „Istra uoči konferencije mira. Talijanska okupacija Istre 1918. i istarski Hrvati“, Zbornik Historijskog instituta JAZU, 4, 1961., 350, 356; Mate Balota, Puna je Pula, Pula - Rijeka 1981., 385-387.

26 Izvješće Sema Benellija od 14. XI. 1920. Dokument preuzet s: https://galileumauctions.com/product/ autografo-di-sem-benelli-scrittore-carteggio-da-pola-armistizio-prima-guerra-mondiale (pristupljeno 4. XI. 2020.).

27 Lavo Čermelj, Slovenci in Hrvatje pod Italijom med obema vojnama, Ljubljana 1965., 101; Herman Buršić, „Nekoliko činjenica o antifašističkog borbi Marčanaca između dva rata i u NOR-u“, Prilozi o zavičaju, 5 , 1988., 139; Spomen-knjiga prigodom 125. obljetnice osnutka udruge Čitaonica u Puli, 111.

28 U travnju 1920. tjednik Pučki prijatelj upućuje poziv omladinskim društvima i hrvatskim čitaonicama u Istri da se „nakon sedamnaestmjesečnoga prekinutog rada opet oživu“. „Omladinskim društvima i 'Hrv. Čitaonicama’ u Istri!", Pučki prijatelj, 16, 16. IV. 1920., 3. 
Činjenica da je Čitaonica bila zatvorena nije spriječila pulske Hrvate da se i dalje nalaze u Narodnome domu. Na neki način Dom je predstavljao posljednju utvrdu hrvatske, kao i općenito slavenske kulture, ali i političko okupljalište za vrijeme talijanske okupacije. S druge strane u manje formalnim okolnostima u prizemlju zgrade organizirale su se i zabave. Eventualne prepirke, nesuglasice s talijanskim „gostima“ bile su pod strogom policijskom prismotrom. Primjerice, nekoliko dana pred Novu godinu krajem 1918. dvojica mladih Talijana „zalutala“ su, „željna zabave i plesa“, u Dom pritom noseći talijanska državna obilježja na odjeći. Odgovorni su na to reagirali tražeći od njih da ih skinu, što mladići nisu prihvatili, već su o tome obavijestili nadležne policijske službe koje su uhitile četiri Hrvata, očito organizatore plesnjaka. ${ }^{29}$ Ne možemo posve odbaciti mogućnost da je spomenuta epizoda nastala spletom nesretnih okolnosti i nesporazuma, ali moglo je to biti i planirano „sondiranje“ terena Narodnoga doma.

U svakom slučaju, osobe koje su pohodile hrvatsko zdanje u Carrarinoj ulici nisu prošle „mimo radara“ talijanskih okupacijskih vlasti. O tome svjedoči i dopis zapovjednika pulskoga karabinjerskog odreda (Divisione CC. RR. Pola) Flavija Landija pulskomu civilnomu komesaru ${ }^{30}$ od 4. XI. 1919., proslijeđen i generalnom civilnom komesaru u Trstu: „Prije rata u Puli je postojala hrvatsko-slovenska čitaonica u Carrarinoj ulici br. 4., prvi kat. Danas je zatvorena. Osobe koje su je prije posjećivale danas se nalaze u kavani 'Narodni dom', točnije u jednoj unutarnjoj prostoriji gdje čitaju i komentiraju novine. Već neko vrijeme obavlja se poseban nadzor nad njima preko za to zaduženoga agenta.“" ${ }^{11}$

29 „Cortesie“, Il Giornaletto di Pola, 1179, 28. XII. 1918., 3.

30 Civilni komesari bili su na čelu okruga (u razmatranom slučaju pulskoga okruga). Kao najvišim organima civilne vlasti bili su im, između ostaloga, povjereni poslovi javne sigurnosti, a odgovarali su generalnom civilnom komesaru u Trstu. Potonji su kraljevskim dekretom od 20. VII. 1919. preuzeli ulogu koju su dotad obnašali vojni guverneri u okupiranima Julijskoj krajini i Južnom Tirolu. Njima je bio povjeren nadzor i više upravljanje svim civilnim službama, kako vladinim, tako i lokalnim. Imali su daleko veće i šire ovlasti od provincijskih (pokrajinskih) prefekta u Kraljevini Italiji i kasnije u novim provincijama, a njihove ingerencije bile su veće i od bivših austrijskih namjesnika, kao i onih bivšega vojnoga guvernera, s istaknuto političkom ulogom. Njihova je dužnost bila da se brinu za pravilno funkcioniranje svih građanskih službi i za održavanje javnoga reda. U njihovu kompetenciju spadalo je i imenovanje svih djelatnika i činovnika u raznim uredima na teritoriju njihove jurisdikcije, kao i imenovanje povremenih službenika. Milivoj Korlević, „Uprava i sudstvo Istre 1918-1945“, Vjesnik historijskih arhiva u Rijeci i Pazinu, 2, 1954., 21 , $24-25$.

31 Državni arhiv u Pazinu (DAPA), HR-DAPA-060, Civilni komesarijat Pula (CKP), kut. 5, 1920. Dopis br. $42 / 3$ od 5. XI. 1919. 


\section{Splitski incident 11. VII. 1920. i palež Narodnoga doma u Trstu - instrumenti medijskoga poticanja nacionalističkoga nasilja}

Splitski incident 11. VII. 1920., ${ }^{32}$ u kojemu su smrtno stradala dva talijanska vojnika i jedan jugoslavenski civil, ni stotinu godina nakon toga događaja nije dokraja razjašnjen, niti kod povjesničara sjevernojadranskoga područja postoji potpuno suglasje oko njegova povoda, ali i dinamike sukoba.

Slovenska povjesničarka Milica Kacin-Wohinz sumirala je u sklopu studije o paleži Narodnoga doma u Trstu događaj na sljedeći način: „12. srpnja (riječ je o 11. VII., op. M. R.) dva mornarička časnika s talijanskoga broda 'Puglia' skinula su u Splitu jednu jugoslavensku zastavu i donijeli je na brod kao trofej. Lokalno stanovništvo, veoma uvrijeđeno, napalo je talijanske mornare koji su došli na obalu, kojima je u pomoć pohitao sam zapovjednik broda. Lokalne policijske snage priječile su privezivanje broda, na što su talijanski mornari odgovorili pucanjem po rivi, ubivši jednoga demonstranta. Policija je odgovorila na pucnjeve i smrtno je pogodila zapovjednika Gullija i strojara Rossija. Incident koji su uzrokovali talijanski mornari, kako je potvrdilo i posebno međunarodno povjerenstvo, postao je povodom nereda u Trstu i drugim krajevima Julijske krajine.“39 Drugačiji pogled na stvari predstavila je talijanska filologinja i arhivistica Valentina Petaros Jeromela. U svojoj studiji usmjerenoj isključivo splitskom incidentu došla je do (općeprihvaćenoga) zaključka da je povod sukoba u kojima su smrtno stradale tri osobe bila zastava. U samoobrani stradali talijanski časnici htjeli su spasiti svoje mornare koji su zastavu htjeli predati savezničkoj upravi u Splitu, dokazujući time da ona nije bila spaljena ni obezvrijeđena na koji drugi način. ${ }^{34}$ Autorica je mišljenja da je vatreno oružje protiv talijanskoga broda prvi upotrijebio srpski vojnik koji se nalazio na rivi. ${ }^{35}$

Usporedbom konzultiranoga novinskoga, arhivskoga gradiva i literature $^{36}$ dviju autorica, s bitno drugačijom optikom i pristupom problemu,

$32 \mathrm{U}$ to vrijeme u Splitu su međ unarodne savezničke snage, de facto pod zapovjedništvom admirala Philipa Andrewsa, zapovjednika američke flote na Jadranu i okolici, kroz mirovnu misiju kontrolirale sporan granični teritorij između Kraljevine SHS i Kraljevine Italije dok se bilateralnim ugovorima ne nađe konačno rješenje. Vjekoslav Perica, „Međ unarodna misija u Splitu nakon Prvog svjetskog rata (1918.-1921.) prema arhivu Ratne mornarice SAD-a i drugim izvorima“, Časopis za suvremenu povijest, 42, 1, 2010., 131, 134.

33 Kacin-Wohinz, „L'incendio“, 89.

34 Valentina Petaros Jeromela, „1 1 luglio 1920: l'incidente di Spalato e le scelte politico-militari“, Quaderni, 25, 2014., 333.

35 Ista, 1918-1921. Fuoco sotto le elezioni. Gli incidenti di Spalato, Trieste e Maresego, Trieste 2018., 10.

36 Primjerice, ne analizira se ni komentira rad Claudija Silvestrija „Documenti americani sui 'fatti di Spalato' del luglio 1920", Il movimento di liberazione in Italia, 1, 1969., 62-81. Autor donosi niz dokumenata admirala Andrewsa o splitskom incidentu koji uvelike rasvjetljavaju zbivanja, ali uz oprezne ocjene oko samoga tijeka incidenta. Silvestri nije naveo ustanovu koja mu je omogućila uvid u citiranu dokumentaciju. Izvjesno je, konzultacijom članka Vjekoslava Perice (vidi bilj. 32), da se dokumentacija nalazi u National Archives and Record Administration u Washingtonu. 
ostaje dojam da razmatrana epizoda i dalje predstavlja istraživački izazov koji bi imao donijeti cjelovitiju kritiku izvora i u konačnici objektivnije teze. U tom smjeru razmišlja, a na tom je tragu i autor ovoga članka, i talijanska povjesničarka Marina Cattaruzza kroz stav da se radilo o jednom od „onih nikada do kraja razjašnjenih incidenata nerasvijetljene dinamike (dinamica oscura) u krajevima o kojima su se vodili pregovori nakon Prvoga svjetskoga rata, a gdje su svoju ulogu političke provokacije vjerojatno odradile tajne službe“. ${ }^{37}$

U tom smislu možemo ponuditi odgovor na pitanje jesu li ondašnji mediji, bilo hrvatski, slovenski ili talijanski mogli i - što je važnije - htjeli objektivno sagledati situaciju. Nisu. Jednako tako ni istaknuti tršćanski i pulski fašisti koji su poveli demonstracije i sudjelovali u izražavanju nasilja spram hrvatskih i slovenskih institucija nisu, naravno, bili vođeni željom za objektivnim sagledavanjem situacije već su iskoristili političku situaciju za nacionalističke konstrukcije i provođenje svojih ciljeva. Možda tu tezu najbolje potvrđuje Gabriele D’Annunzio, čiju je misao prenio talijanski list La Nazione 15. VII. 1920., neposredno nakon paljenja Narodnoga doma u Trstu te onoga u Puli: „Napokon postoji opasnost. A da ne postoji, bilo bi vrijeme da je potražimo (...) Za nas! (...) Drugovi, prljavi srpski svinjar na prijevaru je opet prolio nevinu latinsku krv."38

Istarske i tršćanske, ali i druge talijanske novine, objavile su 13. VII. 1920. vijest o stradanju talijanskih vojnika u Splitu. I dok je najtiražniji talijanski dnevnik Corriere della Sera na drugoj stranici objavio skroman članak „Ozbiljan incident u Splitu. Ubijen zapovjednik 'Puglie“, socijalistički list Avanti! pisao je na posljednjoj stranici „Splitsko stanovništvo protivi se talijanskim časnicima. Pripremaju se novi događaji u Splitu“, a Mussolinijev Il Popolo d'Italia na naslovnici je objavio tekst „Novi neredi u Splitu. Talijanski mornarički zapovjednik i jedan strojar ubijeni“. Najdalje je u prejudiciranju, interpretaciji te instrumentalizaciji zbivanja otišao pulski dnevnik L'Azione naslovnom porukom „Jugoslavenski nacionalisti žele prouzrokovati rat: ozbiljni događaji u Splitu“, prilažući informaciju da su u splitski akvatorij došla tri talijanska ratna broda. U trenutku objave redakcijama nije još bila ni poznata informacija o smrti drugoga časnika (zapovjednika 'Puglie' kapetana

37 Cattaruzza, L'Italia e il confine orientale, 142.

38 „Il pericolo c'è, finalmente. E, se non ci fosse, sarebbe ora di andare a cercarlo [ ... ] A noi! [ ... ] Compagni, il laido porcaro serbo, a tradimento, ancora ha sparso il latin sangue gentile“. Kacin-Wohinz, „L'incendio“, 93. 
korvete Tommasa Gullija). ${ }^{39}$ Diskurs je u navedenim listovima bio sličan, krivnja je bila na Jugoslavenima, ali je retorika ipak bilo mnogo oštrija i huškački impostirana u istarskim talijanskim glasilima koja su tražila „rat“.

Iako je zgrada Narodnoga doma u Trstu bila i prije (1919.) metom nacionalističkih skupina, ${ }^{40}$ glavni i konačni napad - „opravdan“ nužnošću osvete za splitske žrtve, vezujemo za akciju fašističkih skvadri na čelu s Francescom Giuntom u večernjim satima 13. VII. 1920., a pod budnim okom i naklonošcu vojnih snaga koje su ga imale braniti. ${ }^{41}$ Kakav je stav spram fašista imao generalni civilni komesar za Julijsku krajinu Antonio Mosconi, ${ }^{42}$ možda najbolje oslikava njegova ocjena iz veljače te godine, kada je izjavio da „fašisti predstavljaju jedinu organiziranu jezgru u obrani talijanstva i društvenoga poretka“. Ne čudi stoga što vojne snage koje su trebale braniti Dom od demonstranata - fašista, nacionalista i studenata, kako se navodi u službenim izvješćima - nisu intervenirale, već su se i pridružile akciji napada na Dom koji je posve izgorio u narednim satima. ${ }^{43}$

Sljedećega dana, 14. VII., L'Azione je s vidnim uzbuđenjem objavio tekst „Trst uznemiren barbarskim masakrom u Splitu spaljuje 'Narodni dom' i napada jugoslavenski konzulat“. Znakovito je da je prvi dio naslova tiskan većim slovima, što ukazuje na to da se u prvom planu htjelo potencirati talijanske žrtve u Splitu, dok su tršćanske žrtve i uništavanje slovenskih/(jugo) slavenskih ustanova marginalizirani i predstavljeni kao posve logičan slijed događaja. Htjelo se poručiti da počinitelji - time ne i krivci - nisu bili fašisti

39 „Un grave incidente a Spalato. Il comandante della 'Puglia’ ucciso“, Corriere della Sera, 167, 13. VII. 1920., 2; „La popolazione di Spalato contro gli ufficiali italiani. Si preparono nuove avventure in Dalmazia“, Avanti!, 155, 13. VII. 1920., 4; „Nuovi disordini a Spalato. Il commandante navale italiano e un motorista uccisi“, Il popolo d'Italia, 166, 13. VII. 1920., 1; „I nazionalisti jugoslavi vogliono provocare la guerra. Gravissimi fatti a Spalato“, L'Azione, 156, 13. VII. 1920., 1.

40 Napad na Narodni dom u Trstu dogodio se za talijanske okupacije prvi put već 4. VIII. 1919., kada je grupa talijanskih „nacionalista“ reagirala na prosvjede socijalista i izrečene parole protiv Italije, provalivši u tamošnju zgradu Doma i bacala kroz prozor knjige iz pripadajuće joj čitaonice. Također su u tiskari Edinosti spalili dio knjižnoga gradiva. „Gravi disordini a Trieste“, L'Azione, 214, 5. VIII. 1919, 3; Archivio Centrale dello Stato (dalje: ACS), Ufficio centrale per le nuove province (dalje: UCNP), kut. 51, brzojav br. 5539. gen. civ. komesara za Julijsku krajinu Augusta Ciufellija upućen ravnatelju Ureda za nove provincije u Rimu Francescu Salati, 6. VIII. 1919.

41 Zbog pandemije koronavirusa 2020. određ ene dokumente vezane za napade u Trstu i Puli nije bilo moguće konzultirati. Riječ je prije svega o fondu Generalnoga civilnog komesarijata pohranjenom u Državnom arhivu u Trstu. Uvid u tu dokumentaciju dijelom je bio moguć zahvaljujući knjizi Almeriga Apollonija Dagli Asburgo a Mussolini (vidi bilj. 7).

42 Za vrijeme paljenja narodnih domova u Trstu i Puli nalazio se na službenom savjetovanju kod talijanskoga predsjednika Vlade Giolittija i predsjednika Ureda za nove provincije Salate u Rimu. U tom periodu zamjenikom mu je bio Francesco Crispo Moncada. „Giolitti e i commissari delle terre redente“, Corriere della Sera, 172, 18. VII. 1920., 3.

43 Antonio Mosconi, I primi anni del governo Italiano nella Venezia Giulia. Trieste 1919-1922, Bologna 1924., 15-17. O povezanosti vojnih snaga i uspona fašizma u Julijskoj krajini za talijanske okupacije 1918 . - 1920. vidi više u: Marco Mondini, La politica delle armi. Il ruolo dell'esercito nell'avvento del fascismo, Bari 2015., 244. 
već Trst, kao personifikacija ranjenoga talijanstva koje je valjalo obraniti. Usto je podnaslov navodio „otkrivanje oružja“ u Narodnom domu i bacanje bombi (iz smjera Doma), što je imalo stvoriti alibi za napad. U takvoj je ciljano elektriziranoj atmosferi s potenciranom nacionalističkom histerijom, koju je talijanski povjesničar Renzo de Felice nazvao pravim krštenjem organiziranoga skvadrizma, ${ }^{44}$ osvanula Pula 14. VII. 1920. godine. ${ }^{45}$

\section{Tko je i kako napao Narodni dom u Puli? Disonantni tonovi službenih izvješća i medijskih napisa}

Još 13. VII. 1920., kada je u jeku bila akcija skvadrista u Trstu, dio je stanara pulskoga Narodnoga doma u strahu od slične sudbine koja bi ih mogla zadesiti napustio svoje stanove. ${ }^{46}$ Sljedećega dana pulski civilni komesar Giovanni Oriolo naredio je pretres zgrade Narodnoga doma, a obavili su ga na prvome i drugome katu - izuzev prostorija Posujilnice koja je, kako navodi, bila zatvorena - službenici kvesture i karabinjeri u civilu, na čelu s vicekvestorom Giuriatom i brigadirom Licciardellom u popodnevnim satima ${ }^{47}$. Nastavak pretresa bio je predviđen za naredni dan. Pronađen je veći broj telefonskih uređaja, dalekozora, telefonska žica, veći broj geografskih karti, dvije puške, 14 jugoslavenskih i srpskih zastava i dr. Nekoliko dana poslije sekvestrirani materijal $^{48}$ bio je predan zapovjedniku Pomorske utvrde Pula, odnosno Upravi topništva. ${ }^{49} \mathrm{U}$ pogledu „pronalaska“ oružja službena izvješća, kako vicekvestora, tako i civilnoga komesara, jasno navode da „nije pronađeno oružje (...), a sve pronađeno evidentno je pripadalo vojnim vlastima bivše austro-ugarske Vlade“ ${ }^{50}$ Očito su pronađene puške bile neupotrebljive.

44. Renzo De Felice, Mussolini il rivoluzionario 1883-1920, Torino 1965., 624.

45 „Trieste esacerbata per l'eccidio barbaro di Spalato incendia il Narodni Dom' e assalta il consolato jugoslavo“, L'Azione, 157, 14. VII. 1920., 1; Adrian Lyttelton, La conquista del potere. Il fascismo dal 1919 al 1929, Roma - Bari 1974., 86.

46 „Kdo je izvršil zločinski napad v Puli?““, Edinost, 145, 22. VII. 1920., 1.

47 Prema izvještaju vicekvestora Giuriata, datiranom 15. VII. 1920., ta je radnja trajala od 16 do 21 sat, dok će nekoliko mjeseci poslije kapetan pulskih karabinjera De Vita u jednom izvještaju komesaru Oriolu navesti da je pretres bio gotov u 18:30. „Violenta protesta di Pola contro l'assassinio di Spalato“, L'Azione, $158,15$. VII. 1920., 1; DAPA, CKP, kut. 17, 1920., f: C-12. Izvještaj pulskoga vicekvestora državnom prokuratoru, datiran 15. VII. 1920., isto, br. 1797., dopis Oriola Mosconiju od 19. VII. 1920.; isto, br. 346/14, dopis De Vite Oriolu 19. XI. 1920.

48 Dnevnik L'Azione objavio je podatak da je karabinjer Vincenzo Ferrara pronašao iza jedne slike obješene o zid tajno skrovište u kojem je pronađ eno „ni manje ni više nego dva kamiona vojnoga materijala“. Spomenuti Ferrara, rodom Napolitanac, je 23. IX. 1920. - dva dana nakon Mussolinijeva posjeta Puli - ubijen u sukobu s mladim pulskim socijalistima. „Violenta protesta di Pola contro l'assassinio di Spalato“, L'Azione, $158,15$. VII. 1920., 1; Dukovski, Fašizam u Istri, 254.

49 ACS, UCNP, kut. 50, 1920., br. 1797. gab. Dopis Oriola Mosconiju od 18. VII. 1920.; DAPA, CKP, kut. 17, 1920., f: C-12, br. 178/3. Dopis zapovjednika Ureda za javnu sigurnost poslan Civilnom komesarijatu u Puli 22. VII. 1920.

50 Isto, izvještaj pulskoga vicekvestora državnom prokuratoru, datiran 15. VII. 1920.; isto, br. 1797. gab, izvješće Oriola Mosconiju od 19. VII. 1920. 
Prvi izvještaj o ekscesima u Puli koji su uslijedili netom nakon izvršenoga pretresa upućen je Uredu za nove provincije pri Predsjedništvu Vlade u Rimu već pola sata nakon ponoći 15. VII., a potpisao ga je civilni komesar Oriolo na temelju podataka koje mu je pružio kapetan Giuseppe de Vita, zapovjednik karabinjerske satnije za pulsko područje (grad s okolicom). U brzojavu je komesar naveo kako su okupljeni građani nakon uzvika „dolje Hrvati, živjela Italija“ pokušali bersaljere (,strijelci“, posebne postrojbe talijanskoga pješaštva) nakon večernjega koncerta na Portarati navesti da se pridruže domoljubnim demonstracijama. Nakon kratkoga zajedničkoga puta pukovnik bersaljera uspio ih je odvojiti od demonstranata i usmjeriti u vojarnu, dok su se potonji podijelili u dvije skupine i došli pred Narodni dom - prema nekim procjenama njih $120^{51}$ - gdje se nalazio vicekvestor bez prisutnosti karabinjera i vojnih trupa. Vijest o izbodenom arditu ${ }^{52}$, zaključuje Oriolo, „razdražila je duhove čak i kod vojnih osoba, nakon čega se zapucalo na Dom, razbijena su vrata i zapaljen namještaj koji vatrogasci još uvijek gase“ ${ }^{53}$ Ključan „moment“ za razumijevanje korištenoga mehanizma gospodarenja kaosom upravo je pitanje povoda, „okidača“ koji je pokrenuo nezaustavljiv rušilački bijes spram zdanja Doma. I dok Oriolo spominje slučaj navodno ranjenoga ardita, vicekvestor Agostino Giuriato je u svojoj analizi događaja, datiranoj 15. VII., zapisao kako su „s jednog prozora Doma ispaljena dva hica iz pištolja, a što se dogodilo u trenutku kad se proširila vijest o napadnutom desetniku ardita koji je na prijevaru bio ozlijeđen bokserom od jednoga Slavena (u izvorniku: da un Slavo). Prosvjednici su uzvratili s nekoliko hitaca iz pištolja prema prozorima i bacanjem kamenja koje je padalo po vojnicima koji su zbog toga morali ustuknuti od mjesta ulaza u zgradu (... “. ${ }^{54}$

Pulski L'Azione na tom je tragu, ali s bitno većim brojem, pokazat će se izmišljenih i neprovjerenih detalja, uz neskriveno likovanje raspletom

51 Hrvatski državni arhiv, HR-HDA-79, Zemaljska vlada. Odjel za unutarnje poslove, Odsjek za Istru, br. 2905/1920., pismo dr. Mirka Vratovića na temu događaja u Puli od sredine do kraja srpnja 1920. upućeno iz Ljubljane zemaljskoj vladi - povjereništvu za unutarnje poslove u Zagrebu 29. VII. 1920.

52 Naziv koji je Talijanska kraljevska vojska rabila za posebne postrojbe u Prvom svjetskom ratu (u slobodnom prijevodu „smjeli“). Tijekom 1919. i 1920. mnogi arditi su bili bliski s Borbenim fascijima (Fasci di Combattimento) i D'Annunziovom „riječkom pothvatu“ te su i aktivno sudjelovali u njihovim „podvizima“. Postrojbe su potpuno ukinute odlukom premijera Ivanoea Bonomija krajem 1920. De Felice, Mussolini il rivoluzionario, 478; Stefano Peverati, „Gli arditi: 100 anni di valore ed eroismo“, https://secolo-trentino. com/2017/07/30/gli-arditi-100-anni-di-valore-ed-eroismo/ (pristupljeno 18. X. 2020.).

53 ACS, UCNP, kut. 50, 1920., brzojav br. 9523. od 15. VII. 1920

54 DAPA, CKP, kut. 17, 1920., f: C-12. Izvještaj pulskoga vicekvestora državnom prokuratoru, datiran s 15 . VII. 1920 
zbivanja, ${ }^{55}$ već u broju od 15 . VII. objavio reportažu na naslovnici. Oni se tek manjim dijelom mogu objasniti time da je prošlo svega nekoliko sati od delikta do slaganja tiskarskoga sloga. Tako su, primjerice, među pronađenim sumnjivim predmetima pronađene i „puške“ (ne navodeći informaciju o njihovu modelu i broju), a vijest o rezultatima pretresa „duboko je potresla građanstvo“. Kada su demonstranti došli pred Narodni dom, pisao je L'Azione, čuli su hice iz pušaka, što je izazvalo paniku, a istovremeno se u dvorištima okolnih kuća govorilo da su iz hrvatske kuće bačene bombe. Pucnjevi su, nastavlja se, trajali nekoliko minuta, a nije moguće ustanoviti motive pucnjave i bacanja bombi. Vojnici koji su čuvali Dom bili su kamenovani s prozora zgrade - jasno se implicira da se radilo o Hrvatima - a tek je od toga trenutka započeo upad u zdanje. Po dolasku vatrogasaca pojedinci su im htjeli onemogućiti rad, ali nisu uspjeli. U tim trenucima netko ${ }^{56}$ je povikao kako je jedan član ardita (na drugoj stranici list navodi da se to zbilo odmah po dolasku demonstranata) isprebijan pred Radničkom komorom te je pozvao okupljene da krenu u tom smjeru. Međutim, karabinjeri su obišli lokaciju i ustvrdili da je vijest lažna. Tekst završava osvrtom na trojicu ranjenih vojnika: jedan je zadobio ozljedu glave nakon napada muškarca na drugome katu, drugi je prošao gotovo identično s tom razlikom da se drama odigravala na trećem katu, a trećemu vojniku je, također netko nepoznat, ozlijedio ruku željeznim predmetom. Zaključno, list je imao i poruku za pulske Hrvate te im je poručio kako je vrijeme da shvate da su Talijani dugo trpjeli te da nemaju druge opcije nego da pakiraju kovčege. ${ }^{57}$ Bez ikakve sumnje pisanje L'Azionea nije moglo proći bez dogovora s vicekvestorom i komesarom. Sljedećih dana nikakav demanti kao reakcija na niz konstruiranih, lažnih informacija nije objavljen. Ta teza

55 Tako, primjerice, spominje „vatru pročišćenja“, navodi da su stolovi, namještaj, knjige bačeni na lomaču, kako Narodni dom nestaje pred licima mnoštva okupljenih Puljana koji promatraju nestajanje neprijateljske utvrde i „misle kako je povijest na neki način morala izbrisati ono što nije pripadalo ovome gradu i što je vrijeđalo smjernice rimske čistoće“. „Violenta protesta di Pola contro l'assassinio di Spalato“, L'Azione, 158, 15. VII. 1920., 1.

56 U svim budućim službenim izvješćima za osobu koja je zapucala pred Domom uvriježit će se pojam „netko“. Naznaku tko je to mogao biti dao je socijalistički zastupnik u talijanskome parlamentu Cesare Alessandri. On je, prema pisanju lista Il Lavoratore della provincia od 6. VIII. 1920., od talijanskoga premijera tražio istragu na temu „što pulska služba javne sigurnosti čeka s podizanjem optužnice protiv stanovitoga Mugnatija koji je uvečer 19. srpnja (radi se o 14. srpnja, op. M. R.) tijekom napada na 'Narodni dom' pozivao fašiste da upadnu u Radničku komoru, potpuno izmislivši, s evidentno kriminalnom svrhom, da je u prostorijama Radničke komore ubijen jedan vojnik“. Predočene podatke Alessandri je, vjerojatno, dobio za posjeta Puli gdje je pred Radničkom komorom održao politički govor. Ipak, vjerodostojnost podatka iz navedenoga lista, o kojemu nemamo više informacija (nije riječ o tršćanskom dnevniku Il Lavoratore) niti ga je moguće konzultirati (članak je pronađen kao izrezak u fondu Civilnoga komesarijata u Puli pri Državnom arhivu u Pazinu), treba uzeti sa zadrškom. Iz stenograma sjednica talijanskoga parlamenta druge polovice srpnja te prvoga tjedna kolovoza 1920. ne proizlazi da je Alessandri iznio spomenute tvrdnje. DAPA, CKP, kut. 17, 1920, f: C-12; „Il discorso dell'on. Alessandri davanti alla C. d. L.“, L'Azione, 170, 29. VII. $1920 ., 2$.

$57 \mathrm{Na}$ ist. $\mathrm{mj}$. 
dobiva svoju potvrdu i iz upute pulskoga komesara novinstvu i sudstvu da više ne spominju sudjelovanje vojske ${ }^{58}$ u netom završenim neredima. ${ }^{59}$

Vijest su, u mnogo sažetijem obliku, 15. i 16. VII. objavili i drugi talijanski dnevni listovi, između ostaloga i fašistički Il Popolo d'Italia, tvrdeći da je iz Doma zapucano na demonstrante. ${ }^{60}$ Jedini list koji je objavio drugačiju verziju događaja bio je pulski socijalistički dnevnik Il Proletario. U kratkome članku od 15. VII. objavio je vijest kako je prethodne večeri grupa mladića inscenirala prosvjede zbog splitskih zbivanja, potom prepriječila put vojnome orkestru koji se vraćao u vojarnu te se najzad uputila pred Narodni dom, gdje je netko iz okupljenoga skupa dvaput zapucao - jednom iz pištolja, jednom iz puške (moschetto). Nedugo nakon toga, navodi list, plameni jezičci izlazili su iz prozora zgrade. ${ }^{61}$ Pokazat će se da je ta vijest bila najbliža istini. Iz brzojava komesara Oriola Središnjem uredu za nove provincije u Rimu poznato nam je i da je Josip Poduje, predsjednik Radničke komore u Puli i odgovorni urednik Il Proletarija, bio „autorom novinskoga članka protiv vojnih vlasti““62 te je zbog toga 19. VII. 1920. uhićen i odvezen na suđenje u Trst. ${ }^{63}$ Nije teško zamisliti intonaciju Podujina teksta. U svakom slučaju, Il Proletario je - zbog svega što se događalo 1920., ali naravno i zbog drugačijih ideoloških pogleda - bio izrazito kritičan prema potezima koje su vukli pulski komesar i vicekvestor, a time i meta fašistima. ${ }^{64}$

Koji su to elementi „priče“ - osim navodnoga skrivenoga oružja i ranjenoga ardita, što smo već demontirali i dekonstruirali - u službenim izvješćima i medijima rabljeni kao alibi za prikrivanje zločina? Svakako je potrebno odgovoriti na sljedeća pitanja: je li vojska čuvala Narodni dom prije dolaska prosvjednika, tko je prvi zapucao i iz kojega smjera, jesu li uz fašiste-demonstrante službene osobe sudjelovale u neredima i je li izgrednicima pružen otpor.

58 Vicekvestor Giuriato potvrdio je 6. VIII. 1920. u dopisu civilnom komesaru da su događaji u Trstu i Puli bili posljedica eksplozije „najsmionijih među Talijanima“ ( gli piu arditi degli Italianı), potpomognutih značajnim brojem vojnih osoba. DAPA, CKP, kut. 17, 1920., f: C-12, br. 1945. Gab.

59 DAPA, CKP, kut. 17, 1920., f: C-12, br. 1797., dopis od 19. VII. 1920.; ACS, UCNP, kut. 50, 1920., br. 1798 gab. Dopis Oriola Mosconiju 19. VII. 1920.

60 „Le ripercussioni a Pola e Fiume“, Il Popolo d'Italia, 169, 16. VII. 1920., 4.

61 „I fatti di ieri sera“, Il Proletario, 218, 15. VII. 1920.

62 Navedeni članak nije bilo moguće konzultirati jer je list Il Proletario, prema autorovim saznanjima, sačuvan tek u fragmentima

63 ACS, UNCP, kut. 53, 1920., br. 9783. Dopis datiran 19. VII. 1920., poslan u Rim 20. VII. 1920.

64 Tršćanski socijalistički list Il Lavoratore della sera pisao je 30. IX. 1920. kako „civilni komesar Oriolo i vicekvestor Giuriato naoružavaju Mussolinijeve sljedbenike i usmjeravaju ih da održe prisegu koju su protiv nas (socijalista, op. M. R.) položili u Fasciju Grion“. „Dopo le gesta teppistiche dei fascisti a Pola“, Il Lavoratore della sera, 30. IX. 1920. U: DAPA, CKP, kut. 17, 1920., f: C-12. 
Sam komesar Oriolo će 19. VII. u dopisu Mosconiju korigirati svoje prvo izvješće i navesti „kako se pretpostavljalo da će prosvjednici doći pred Narodni dom pa je zato određeno da zdanje čuva pedeset vojnika i deset karabinjera“. No, oni nisu mogli spriječiti, nastavlja, navalu demonstranata kojima se pridružio i veći broj vojnika u uniformi. Provela se defenestracija namještaja, a u više je prostorija na prvome i drugome katu podmetnut požar. ${ }^{65}$ Problematika pucnja posebno je zanimljiva i važna. Krucijalno je u tom smislu izvješće koje je Oriolu uputio zapovjednik pulskih karabinjera Giovanni De Vita. On je zapisao kako su se vojnici odmaknuli od zgrade nakon što su je prosvjednici kamenovali, nakon čega je „iz mnoštva netko, nije se moglo ustanoviti tko, zapucao iz pištolja, a u tom trenutku je netko bacio i oveći kamen u prozor Doma, što je stvorilo prasak koji je podsjetio na tršćansku epizodu prethodne večeri (teoriju da je iz tamošnjega Doma netko zapucao na demonstrante). Tada su bersaljeri počeli pucati po Domu“. Iako je vjerojatno bio upoznat s dotadašnjim službenim diskursom, a svakako s medijskim napisima o ranjenim vojnicima, De Vita je jasno dao do znanja da je tek jedan vojnik ozlijeđen, i to „nedvojbeno u mračnim i konfuznim uvjetima u naletu demonstranata ili pak ozlijedivši se o kakav čavao ili krhotinu namještaja“. Teza o iznenadnim napadima nepoznatih osoba ${ }^{66}$ na vojnike pada u vodu. Kao zanimljivost, koju se u ostalim dokumentima ne raščlanjuje, satnik je naveo da su u požaru ostala sačuvana dva sefa Istarske posujilnice - jedan je sadržavao novac, a drugi dokumente. ${ }^{67}$ Moguće je da su ti predmeti, zajedno s onima konfisciranim u premetačini, završili u prostorijama Uprave Arsenala do sudskoga očevida, a što je bilo s njima poslije konzultirano gradivo nam ne otkriva.

U De Vitinu vjerodostojnost ne trebamo sumnjati iz više razloga. Prije svega, njegov dolazak u Pulu na delikatno i odgovorno mjesto satnika karabinjera zbio se početkom svibnja $1920 .{ }^{68}$ te je nesumnjivo bio „provjereni kadar“

65 Isto, kut. 50, 1920., br. 1798 gab. Dopis Oriola Mosconiju od 19. VII. 1920.

66 Prema sjećanjima Josipa Iveše - od 1914. do 1918. dopredsjednika nogometnoga kluba i tamburaškoga zbora sastavljenoga od radnika Arsenala koji su prije rata redovito pohodili Narodni dom - u Domu se u vrijeme paleži zatekao tek jedini i posljednji službenik Istarske posujilnice Ante Mezulić, koji je u tim prostorima i noćio, te se po paljenju spasio skokom s prvoga kata u dvorište sa stražnje strane zgrade. Nedugo potom emigrirao je u Zagreb. Josip Iveša, „Tvrđava istarskih Hrvata“, Glas Istre, 45, 4. XI. 1961., 5.

67 DAPA, CKP, kut. 17, 1920., f: C-12., br. 346/3, dopis De Vite Oriolu od 16. VII. 1920.

68 Nakon 15. V. 1920., vrlo vjerojatno kao posljedica tragičnoga prvomajskoga sukoba u Puli između karabinjera i prosvjednika, dolazi do velike smjene karabinjerskih snaga pa dolazak De Vite možemo uvjetno promatrati i u tom kontekstu. DAPA, CKP, kut. 17, 1920., f: C-12. Dopis zapovjednika pulskoga karabinjerskog odreda (Legione carabinieri di Trieste - Divisione di Pola), pukovnika Ameriga Reggia, upućen civilnom komesaru Oriolu 8. IX. 1920. 
bez posebnoga senzibiliteta spram „hrvatskoga pitanja“ u Istri. ${ }^{69}$ Potom, vrijedi zamijetiti da njegova izvješća o zbivanjima oko Narodnoga doma nisu, slijedeći protokol, bila upućena najvišim političkim instancama u Trstu i Rimu, kao ni medijima već njemu izravno nadređenoj osobi - civilnom komesaru - koja je tražila podatke o tome što se doista dogodilo. Naravno, komesar je ta saznanja sačuvao za sebe i preoblikovao u mjeri za koju je smatrao da mu konvenira u korespondenciji sa središnjom vlasti u Rimu.

Nužno je osvrnuti se i na pojam „demonstranata“ i „nacionalista“ prisutan u svim službenim izvješćima pulskih vlasti te medijima. Poznato je da je 12. VII. 1920. u Puli službeno osnovan Fascio di Combattimento na čelu s bivšim talijanskim dragovoljcem u Velikom ratu te potom D’Annunziovim riječkim legionarom Luigijem Bilucagliom. Fascio je za L'Azione 14. VII. 1920. otvoreno izjavio da se nakon splitskih događaja „hitno sastao njegov izvršni odbor te zaključio kako poziva čitavo građanstvo da pokaže pripadnost Italiji time što će se na njihov poziv pridružiti fašističkoj oružanoj akciji kako bi se obranila Domovina izvana i iznutra. "70 Točan broj ili postotak fašista među demonstrantima nije moguće ustanoviti, ali nesumnjivo je njihova uloga bila presudna, dirigirajuća u nasilnome izražavanju nacionalističke ksenofobije.

Slične intencije fašisti su nastojali materijalizirati i u drugim lokacijama gdje je bilo bitno obračunati se s ,inorodnim elementom“: tiskara Pučkoga prijatelja u Pazinu potpuno je uništena uvečer 15. VII., dok je tamošnji Dom, pisala je tršćanska Edinost, bio pošteđen uništenja zato što su u njemu živjeli talijanski časnici. U noći 16. na 17. VII. više je hrvatskih kuća u Pazinu bilo označeno križevima, a kolali su tiskani letci s porukom „za sada vas označavamo, a kasnije ćemo vas uništiti“. U Rijeci su uništene „Hrvatska agrarna banka“, „Zadružna banka“ (Banca cooperativa), više kavana, knjižnica i knjižara, trgovina te pet jugoslavenskih jedrenjaka. ${ }^{71}$ Dakle, metu su predstavljale hrvatske organizacije, ustanove, nekretnine i pokretnine, odnosno sve što se moglo promatrati kao intelektualni i financijski temelj hrvatske prisutnosti u okupiranim zemljama.

69 „Trasferimenti nell'arma dei RR. CC.“, L'Azione, 98, 7. V. 1920., 2.

70 „La costituzione del Fascio di combattimento - Sezione di Pola“, L'Azione, 156, 13. VII. 1920., 2; Volontari delle Giulie e della Dalmazia, dati raccolti e ordinati a cura di Federico Pagnaco, seconda edizione, Trieste 1930., 409; Dukovski, Fašizam u Istri, 54.

71 „Divljanje Italijanov na Reki“, Slovenec, 159, 16. VII. 1920., 1; „Žaloigra minulega torka in italijansko časopisje“, Edinost, 145, 20. VII. 1920., 1. Navedeni članak iz Edinosti dospio je tada i u kabinet Generalnoga civilnog komesarijata u Trstu. ACS, UCNP, kut. 50, 1920.; Apollonio, Dagli Asburgo a Mussolini, 312. 


\section{Osvetnički pohod na stanove odvjetnikā Mirka Vratovića i Ive Zuccona}

Dok se 15. VII. 1920. iz zdanja na adresi Carrarina 5 još širio miris zgarišta, fašisti su planirali novi „osvetnički“ pohod. Dva su bila cilja: Klub socijalističke mladeži na pulskome Velom vrhu ${ }^{72}$ te stanovi i odvjetnički uredi dr. Mirka Vratovića i dr. Ive Zuccona na pulskoj Rivi. Nesumnjivo su ta dvojica prekaljenih hrvatskih političara i pravnika bili duže vremena pod njihovom prismotrom. Zuccona su - spomenimo da je obnašao dužnost predsjednika pulske Čitaonice pred Prvi svjetski rat ${ }^{73}-$ u ožujku 1919. talijanske okupacijske vlasti internirale na šest mjeseci u Rim, ali je po povratku u Pulu nastavio sa svojom pravnom praksom i tražio od Središnjega ureda za nove provincije pri Predsjedništvu vlade puštanje na slobodu više interniranih istaknutih Istrana Hrvata (don Luke Kirca, dr. Šime Kurelića i dr.). ${ }^{74}$ Obojica su imali svoje advokature i kućanstva - Zuccon na prvome, a Vratović na drugome katu - u monumentalnoj zgradi (Hotel Miramar) u vlasništvu Vratovićeva oca Grge.

O nasrtaju fašista na njegov dom Vratović je nakon dolaska u Ljubljanu krajem srpnja iste godine napisao podužu promemoriju. Bivajući oko 19 sati (15. VII.) obaviješten iz privatnih krugova da su fašisti odlučili napasti njegovu i Zucconovu pisarnu uputio se (u 20 sati) na kvesturu, gdje je informirao činovnika što bi se moglo dogoditi. Vicekvestora nije bilo, ali mu je, prema Vratovićevim zapisima, službenik nakon pola sata javio da je stupio u kontakt s njim te mu je prenio da je sve poduzeto kako se ništa ne bi zbilo u tom smislu. Životno je iskustvo Vratovića nagnalo da potom (u 21 sat) zatraži da državni odvjetnik Giacomo Steffè pođe osobno komesaru Oriolu i informira ga o svemu. I on je zajamčio da je „svaka moguća navala isključena“. Međutim, oko 1:30 iza ponoći 30 do 40 mladića „s oficirima i arditima nakon što su navalili na Družbinu školu na Velem Briegu i sve razbili“ “75 došli su pred kuću na adresi Viktora Emanuela 6. Pribavivši ključ od jednoga stanara, ušli

72 U tamošnjoj je sekciji Kluba socijalističke mladeži u večernjim satima 10. VII. 1920. održana zabava kojoj je prisustvovalo oko 400 osoba. Događaj je bio prismotrom karabinjera, a nije zabilježen nikakav incident. Dnevnik L'Azione ustvrdio je u broju od 18. VII. da su demonstranti zabunom upali u Socijalistički klub, misleći da se radi o „kući jugoslavenskih nacionalista“ gdje se propagirala protutalijanska politika. DAPA, CKP, kut. 17, 1920., f: C-11, br. 105/255; „Chi ha insegnato il metodo della violenza?“, L'Azione, 161, 18. VII. 1920., 1.

73 Na toj je dužnosti bio 1907., 1908., 1913. i 1914. Spomen-knjiga prigodom 125. obljetnice osnutka udruge Čitaonica u Puli, 133-134.

74 ACS, UNCP, kut. 138, 1920., policijsko izvješće/promemorija upućeno šefu Ureda za nove provincije, Francescu Salati u Rimu 26. XI. 1919.

75 Zapovjednik pulskoga karabinjerskog odreda Amerigo Reggio, koji je imao ingerenciju nad čitavim istarskim područjem, iznosi podatak da je Klub na Velom vrhu napalo oko 150 nacionalista, što nas navodi na zaključak da se nakon toga izgreda izdvojila manja grupa koja je krenula prema Rivi. DAPA, CKP, kut. 17, 1920., f: C-12, br. 603/5, dopis upućen Civilnom komesaru 16. VII. 1920. 
su u dvorište i zgradu te provalili u Zucconov stan - srećom se odvjetnik sa svojim ukućanima skrio netom prije toga kod nekoga od stanara na trećemu katu. Sjekirama su razbijali stakla i bacali pokućstvo kroz prozor. Potom je red došao na Vratovića, čiji su stari otac (75) i majka (67), tri njegove sestre i tri nećakinje (3 - 6 godina) pobjegli skokom s drugoga na prvi kat susjedne kuće. On je u međuvremenu obavijestio hitno telefonom kvesturu i karabinjere te zahtijevao pomoć koja nije došla do okončanja nemile scene. Otvorivši vrata, nazočne je - dvojicu ardita opasanih bombama i još trojicu, četvoricu mladića - upitao kada je on to napao talijanski narod. Pozvao ih je da, kad su već naumili uništavati imovinu, unište njegove sobe i inventar $u$ njima upozoravajući da će time prije svega napraviti štetu njegovim starim roditeljima i klijentima. ${ }^{76}$ Konačno, obećao im je da će se iseliti iz Pule ako prestanu s devastacijom. Sljedećega dana, 16. VII., provedena je premetačina u stanovima Vratovića i Zuccona u kojima je pronađeno šest ručnih bombi, ali su karabinjeri odustali od uhićenja jer su posumnjali da su im ih provalnici podmetnuli. Ipak, Zucconu je vicekvestor prenio da mu ne mogu jamčiti sigurnost za život pa je bio prisiljen napustiti zavičaj već 20. VII. 1920. Nadalje, 19. VII. 1920. osobni tajnik komesara Mario Bocini (prema Vratoviću, pripadnik fašista) priopćio je samome Vratoviću da je istjeran iz područja stare i nove Italije te je 28. VII. 1920. i on morao napustiti grad i preko Trsta doputovati do Ljubljane. Vratović navodi da je tih dana iz Pule bilo protjerano još 30 „Jugoslavena“, dok su se u drugim krajevima Istre vodili slični „pogromi“"77

Vratovićeva strana priče mogla bi biti shvaćena kao subjektivna, ali L'Azione je bez ustezanja prenio gotovo identičnu faktografiju, ističući da su nakon upada u hrvatsku kuću na Velom vrhu demonstranti uništili i bacili na cestu Zucconov namještaj te pronašli, između ostaloga, šest bombi i jugoslavensku zastavu, dok se odvjetnik Vratović „izvukao s obećanjem da će otići čim riješi pravna pitanja. Prosvjednici su mu učinili milost“ ${ }^{78}$

Odlaskom Zuccona i Vratovića iz Pule, u trenutku kad su stari hrvatski prvaci poput Matka Laginje, Lovre Škaljera i drugih već neko vrijeme bili u

76 „Kdo je izvršil zločinski napad v Puli?“, Edinost, 145, 22. VII. 1920., 1; HDA, Zemaljska vlada. Odjel za unutarnje poslove, Odsjek za Istru, br. 2905/1920., pismo dr. Mirka Vratovića upućeno Kraljevskoj hrvatsko-slavonskoj zemaljskoj vladi, povjereništvu za unutarnje poslove 29. VII. 1920.; Mirko Vratović, „Prije 34 godine spaljen je Narodni dom u Puli“, Glas Istre, 27, 11. VII. 1953., 5.

77 HDA, Zemaljska vlada. Odjel za unutarnje poslove, Odsjek za Istru, kut 16. Pismo dr. Mirka Vratovića upućeno Kraljevskoj hrvatsko-slavonskoj zemaljskoj vladi, povjereništvu za unutarnje poslove 29. VII. 1920.; DAPA, CKP, kut. 17, 1920., f: C-11. Dopis zapovjednika pulske karabinjerske divizije, pukovnika Ameriga Reggia, upućen civilnom komesaru Oriolu 8. IX. 1920.; Mirko Vratović, „Iz mojih zapisaka: događaji u Puli sredinom jula 1920.“, Glas Istre, 278, 16. VII. 1946., 4.

78 „L'assalto alla casa croata a Montegrande e allo studio dell'avvocato Zuccon“, L'Azione, 159, 16. VII. 1920., 2. 
Kraljevini SHS, čitav je kotar ostao bez istaknutih hrvatskih intelektualaca, time i bez povjerenika-izvjestitelja Odbora za Istru pri Zemaljskoj vladi u Zagrebu, osnovanoj 1919. i ovlaštenoj za poslove na području Istre dok se ne riješi pitanje njezine pripadnosti pa se ubuduće moglo u tom pogledu računati tek na istarsko svećenstvo. ${ }^{79}$

\section{Reakcije u talijanskom parlamentu $\mathrm{i}$ ishod službene istrage}

Glas protiv fašističke samovolje u Istri, nadiranja fašističkih skvadri, čuo se nakon srpanjskih događaja i u središnjoj talijanskoj političkoj areni. Zastupnik u parlamentu, socijalist Giovanni Cosattini na sjednici 9. VIII. 1920. upozorio je da su izgredi protiv Slavena u Trstu, Pazinu, Puli svakako zločini prouzrokovani nacionalističkim nasiljem druge strane (jugoslavenske, misleći i na splitski incident, op. M. R.), ali su svejedno „sramota koju je nemoguće prihvatiti u građanskom društvu“. Nastavio je riječima: „Vaša policija, tako spremna za masakr radništva, ostala je pred njima inertni i pasivni promatrač. (...) A ako zaista želite sprïječiti i ujedno pokazati vaše žaljenje za nasiljem nad građanima, za opljačkanim i spaljenim kućama, uništenim bibliotekama i organizacijama Slaveni i socijalisti bili su žrtvama - podmirite nepoštenu štetu koja je nastala zbog vaše nesposobnosti. Samo na taj način odmaknut ćete se od odgovornosti za fašističku neodgovornost“ ${ }^{80} \mathrm{No}$, čini se da Mussolinija nisu brinuli pritisci u parlamentu. U svom prvom, a pokazat će se i jedinom, dolasku u Pulu 21. IX. 1920. održat će govor u pulskom kazalištu (Politeama Ciscutti), gdje će javno izreći/,priznati“ da su upravo (njegovi) fašisti spalili narodne domove u Trstu i u Puli, ${ }^{81}$ a što će ponoviti u listu Popolo d'Italia tri dana poslije tvrdeći da u Julijskoj krajini pravu vlast predstavljaju Fasci di Combattimento, uz opasku kako je sudbonosnim činom (uništenja domova) utakmica završila u njihovu korist. ${ }^{82}$

Neovisno o dotadašnjem nečinjenju sudskih vlasti, uporan i konkretan u svome nastupu (10. XI. 1920.) bio je socijalistički zastupnik Cesare Alessandri

79 HDA, Zemaljska vlada. Odjel za unutarnje poslove, Odsjek za Istru, kut. 16, br. 2905/1920. Odgovor Kraljev. Hrvatsko-slavonske zemaljske vlade, povjereništva za unutarnje poslove M. Vratovića o situaciji u Istri u drugoj polovici srpnja 1920. od 13. VIII. 1920.

80 Camera dei deputati (CDD), Atti Parlamentari (AP), Legislatura XXV, 1. Sessione, Discussioni, Tornata del 9 Agosto 1920, Roma 1920., 5294.

81 Prema izvještaju dnevnika L'Azione od 22. IX. 1920. Mussolini je u govoru domove u Trstu i Puli nazvao hrvatskima, što jasno naznačuje, neovisno o činjeničnome stanju, antagonizam spram istarskih Hrvata. „Il discorso di Mussolini al Ciscutti“, L'Azione, 214, 22. IX. 1920., 2.

82 Benito Mussolini, „Il meraviglioso movimento fascista nella Venezia Giulia (Per telefono al 'Popolo d'Italia')“, Popolo d'Italia, 229, 24. IX. 1920., 1; Giorgio Alberto Chiurco, Storia della rivoluzione fascista, volume II, Anno 1920, Firenze 1929., 270; Benito Mussolini, Opera omnia, XXXV, Aggiunte: scritti e discorsi-lettere - telegrammi - messaggi - cronologia essenziale dal 13 settembre 1943 al 28 aprile 1945, a cura di Eduardo e Duilio Susmel, Firenze 1962., 69. 
sa zahtjevom upućenim predsjedniku Vlade / ministru unutarnjih poslova da provjere jesu li organi javnoga reda u Puli proveli istragu i identificirali počinitelje u vezi s napadom na pulski Narodni dom i na Klub socijalističke mladeži na Velom vrhu. ${ }^{83}$

Tko se trebao pobrinuti za provođenje policijske istrage na temelju koje bi se pokrenuo sudski postupak protiv pojedinaca koji su prekršili zakon? Karabinjeri i kvestura. Međutim, upravo su oni nazočili, dopustili pa i sudjelovali u izgredima. Oriolov stav prema fašistima bio je u najmanju ruku permisivan: u osvrtu (od 28. IX. 1920.) na političku situaciju u Puli tijekom 1920., a koji je Mosconi proslijedio Središnjem uredu za nove provincije pri talijanskoj Vladi (Presidenza del Consiglio dei Ministri) ustvrdio je da je po osnivanju Fascio di Combattimento (u Puli, op. M. R.) uistinu u vojnim vlastima pronašao značajno ohrabrenje i pomoć. ${ }^{84}$ Od lokalnih je vlasti, stoga, bilo naivno očekivati objektivnu analizu zbivanja, kao i temeljitu istragu koja bi bez oklijevanja ukazala na krivce. Ipak je Ministarstvo unutarnjih poslova na zahtjev spomenutih poslanika u parlamentu pokrenulo redovnu proceduru pribavljanja informacija koje su nužno - s obzirom na to da nije osnovano posebno istražno povjerenstvo, ${ }^{85}$ što je bilo i logično jer bi time Vlada na čelu s liberalom Giolittijem u delikatnoj političkoj situaciji diplomatskih pregovora oko granica potkopala vjerodostojnost okupacijskih vlasti - morale doći iz pulskoga kruga službi sigurnosti, podređenih civilnome komesaru.

Karabinjerski satnik De Vita je na upit civilnoga komesara Oriola o rezultatima istrage o događajima iz sredine srpnja odgovorio da je ona provedena

83 CDD, AP, Legislatura XXV, 1. Sessione, Discussioni, Tornata del 10 Novembre 1920, Roma 1920., 3572.

84 Vezano za paljenje Narodnoga doma u Puli i ulogu fašista nedvosmisleno je napomenuo: „U jednom trenutku, koji je kulminirao događajima sredinom prošloga srpnja, odvažnost fašista, sigurnih u protekciju i asistenciju vojnih vlasti, činila se i odveć opasna po održavanje javne sigurnosti. Uljudni, ali odlučni postupci koje sam sproveo spram vojnih vlasti povratili su javni red i mir te spriječili da nacionalisti pokrenu inicijativu za novim nasilnim pothvatima." Oriolo je time potvrdio da je bio upoznat s okolnostima i protagonistima paljenja Doma u Puli, ali je odgovornost prebacio na vojne postrojbe prisutne u Puli, prikazavši sebe kao medijatora koji je spriječio eskalaciju nasilja. U ovom kontekstu indikativno je i svjedočanstvo Mirka Vratovića, koji je zapisao kako se u vrijeme upada „ardita i oficira“ u njegovu kuću na Rivi u blizini našao i talijanski admiral - izgledno je da je mislio na viceadmirala Diega Simonettija - koji ih je tek zamolio da mu naprave uslugu i ne zapale zdanje. HDA, Zemaljska vlada. Odjel za unutarnje poslove, Odsjek za Istru, kut. 16, br. 2905/1920. Odgovor Kraljev. Hrvatsko-slavonske zemaljske vlade, povjereništva za unutarnje poslove M. Vratovića o situaciji u Istri u drugoj polovici srpnja 1920. od 13. VIII. 1920.; ACS, UCNP, kut. 50, dopis Mosconija br. 14/448 od 28. IX. 1920. upućen talijanskoj Vladi, Središnjem uredu za nove provincije i Ministarstvu unutarnjih poslova - Generalnoj direkciji za javnu sigurnost.

85 Generalni civilni komesar na to je imao pravo, što nam ukazuje njegova odluka o izboru posebnoga istražnog povjerenika, komendatora Giovannija Airolda, upućenoga u Pulu nakon tragične epizode 1. V. 1920., a s ciljem odgovora na istragu koju je u talijanskom parlamentu zahtijevao socijalistički zastupnik Francesco Rossi tražeći pritom smjenu vojnih djelatnika krivih za smrt četvorice demonstranata. CDD, AP, Legislatura XXV, 1. Sessione, Discussioni, Tornata del 6 Maggio 1920, Roma 1920., 1971; „L'inchiesta sui fatti di primo maggio“, L'Azione, 97, 6. V. 1920., 1. 
s dužnom pozornošću s ciljem identifikacije odgovornih za palež Narodnoga doma i upad u Socijalistički klub na Velom vrhu. Međutim, rezultata nije bilo jer „nitko nije htio svjedočiti i pružiti podatke protiv bilo koga“. Upad u Dom bio je, navodi De Vita, brz i nasilan i nije se moglo razaznati tko je prvi ušao u zgradu i potom potpalio vatru. Sjedište socijalista, nastavlja, smješteno je na perifernoj gradskoj lokaciji pa se invazija mogla provesti iznenadno. ${ }^{86}$ Pulski vicekvestor bio je još odrješitiji u ekskulpiranju izgrednika. Njegov se stav o razmatranom pitanju ogledao u tome da utvrđivanje odgovornosti pojedinaca otežano napreduje, što stoga jer se radilo o iznenadnom pokretu u kojem su svi prosvjednici zajednički nastupali, što zato što su snage javne sigurnosti „osupnute u tim trenucima vibriranjem njihove talijanske duše“ bile inertne pred njima. Konačno, završava vicekvestor, nitko nije podigao nikakvu optužnicu jer nitko pa ni socijalistički list Il Proletario nije pružio nikakvo svjedočanstvo. ${ }^{87}$ Ipak, pulski socijalisti bliski Proletarïu tražili su od L'Azionea da im priopći dva imena koja se vezuju za akciju na Velom vrhu, kako bi započeli dijalog, no bez uspjeha. ${ }^{88}$

Summa summarum, nitko od napadača na Dom, Klub socijalista i kućanstva na Rivi nije uhićen ni procesuiran, dok su - reda radi - pojedini niži časnici dobili opomenu lokalnih vlasti. ${ }^{89}$ Vicekvestor Giuriato bit će, pak, za svoju „briljantnu policijsku aktivnost“ nagrađen premještajem u rimsku kvesturu listopada iste godine. ${ }^{90}$ Pravni sustav je zakazao u svrhu talijanskih političkih i teritorijalnih ciljeva.

\section{„Samo dvije ostale" - kulturocid Javne pučke knjižnice}

U konzultiranim službenim izvještajima ne nailazimo na podatak o materijalnim štetama vezanima za pokretnine hrvatskih društava u Narodnome domu pa tako ni podatak o broju spaljenih knjiga Javne pučke knjižnice. U stručnoj literaturi moguće je pronaći podatak (kojemu se ne navodi izvor) o 7000 spaljenih knjiga koji je, čini se, prvi iznio dnevnik Glas Istre $1959 .{ }^{91}$ Točan broj spaljenih knjiga teško da će se ikada utvrditi, što i nije od presudne važnosti u razmatranju toga čina u kontekstu neupitnoga kulturocida.

86 DAPA, CKP, kut. 17, 1920., f: C-12, br. 346/9. Dopis od 5. VIII. 1920.

87 Isto, nedatirano izvješće (vjerojatno studeni 1920.) pulskoga vicekvestora pulskom civilnom komesaru u kojem se poziva na zahtjev za istragom zastupnika Alessandrija.

88 „Si son svegliati...", L'Azione, 165, 23. VII. 1920., 2.

89 Apollonio, Dagli Asburgo a Mussolini, 302, 312.

90 „Il cav. Giurati nominato a Roma“, L'Azione, 246, 29. X. 1920., 2.

91 „Teški uvjeti života Hrvata i Slovenaca pod talijansko-fašističkom okupacijom“, Glas Istre, 31 , 31 . VII. 1959., 5; Dobrić, „Udruga Čitaonica“, 29; Stipanov, Povïjest knjižnica, 144. 
Međutim, imajući u vidu da je o toj temi dosad objavljeno relativno malo podataka, a nije posve efemerna, valja se na nju osvrnuti bar na bazičnoj razini.

U Sveučilišnoj knjižnici u Puli do danas je ostala sačuvana jedna knjižica, dar carskoga i kraljevskoga pomorskog pukovnika Dušana pl. Preradovića novoosnovanoj Pučkoj knjižnici 1909., Slike iz obćega zemljopisa Ivana Hoića (Zagreb 1892.). Druga sačuvana knjiga, Njemačka književnost do smrti Goetheove Roberta Pintera (Zagreb 1897.), čuva se u pulskoj Gradskoj knjižnici i čitaonici. ${ }^{92}$

Što se tiče sadržaja knjižnoga fonda, prema knjižničaru Brunu Dobriću, može se pretpostaviti da je Knjižnica posjedovala uglavnom izdanja Matice hrvatske i Društva sv. Jeronima, koja su tada u Istri bila veoma čitana. ${ }^{93} \mathrm{U}$ prilog toj tezi ide i popis spaljenih pokretnina obitelji Fabijančić, stanara na trećemu katu Doma, na kojem su uredno popisane i stradale knjige. Obitelj je tako prijavila izrazito bogat književni fond, ${ }^{94}$ u kojem je navedena i kompletna izdavačka djelatnost Matice hrvatske od 1887. do $1915 .{ }^{95}$ sa svim prijevodima grčkih i rimskih klasika. Gotovo je sigurno da se radilo o knjigama Javne pučke knjižnice (I. kat), koje su u dramatičnim (po)ratnim okolnostima našle privremeno „utočište“ u stanu te obitelji, moguće i u danima koji su prethodili paljenju. Ukupno možemo govoriti o oko 1000 do 1500 svezaka knjiga, što je moglo činiti tek jezgru gradiva Knjižnice.

Fond je nastajao kroz više od pola stoljeća od osnivanja Čitaonice. Zahvaljujući novinskim izvještajima, saznajemo da su udruženja koja su zajednički osnovala Pučku knjižnicu prethodno imala svoje knjižnice. Uz Čitaonicu, osnovanu još 1869., što upućuje na zaključak da je činila temelj fonda Knjižnice, svoju zbirku je koncem 1907. počela prikupljati Narodna radnička organizacija, a aktivna je bila i ona Prvoga istarskog sokola. ${ }^{96}$ Novi zamah u prikupljanju knjiga dogodio se u povodu osnivanja Knjižnice 1909. Primjerice,

92 Zahvaljujem Brunu Dobriću iz Sveučilišne knjižnice u Puli i Nadiji Bužleta iz Gradske knjižnice i čitaonice Pula na pruženim podacima.

93 Dobrić, „Udruga Čitaonica“, 47-48.

94 Uz Matičina, na popisu su bila i sljedeća izdanja (izvornim redoslijedom): Leksikon Mayer (17 svezaka), Roteckova (Karl von Rotteck) Univerzalna povijest (12 svezaka), razne povijesne knjige: o Francuskoj revoluciji, o Rusko-japanskom (ratu?), talijanska i engleska književnost, Filipovićev rječnik (3 sveska), Wolfov rječnik (2 sveska), Weberov rječnik (2 sveska), Slovenski odvjetnik Ružnov (vjerojatno se misli na knjigu Tumač obćem austrijanskom gradjanskom zakoniku I - II, autora Adolfa Rušnava, op. M. R.), izdanja Prosvjete - Dom i svijet (4 godišta), djela Schillera (5 svezaka) i Goethea (3 sveska), Danteova Božanstvena komedija (4 sveska), pjesništvo Prešerna, Gregorčiča, Preradovića, Petrovića-Njegoša, više različitih knjiga svjetske književnosti, 300 knjiga na hrvatskom (lingua slava) jeziku, 180 na njemačkome, 103 na talijanskome te 60 knjiga na francuskome jeziku. DAPA, CKP, kut. 17, 1920., f: C-12. Popis inventara obitelji Fabijančić.

95 U tom je razdoblju Matica objavila 323 sveska. Detaljni popis dostupan na: https://www.matica.hr/media/ uploads/bibliografije/01_bibl.mh_1842-1992.pdf (pristupljeno 16. X. 2020.).

96 „Darujte knjige“, Omnibus, 791, 2. XII. 1907., 1; „Sokolašima“, isto, 1068, 21. I. 1909., 1. 
Društvo sv. Jeronima tom je prigodom i u tu svrhu poklonilo stotinu svezaka knjiga, a Matica slovenska devet svezaka. Dušan pl. Preradović, pak, darovao je u više navrata čak 216 svezaka knjiga, a Frano Pavelić $16 .{ }^{97}$ Kako je u to vrijeme Pučka knjižnica u pazinskom Narodnome domu brojila šest stotina izdanja, a već 1914. ukupno 1510 djela (u 2200 svezaka), moguće je da je pulska Knjižnica već po osnivanju brojila više tisuća svezaka te da je do 1914 . tendencija obogaćivanja knjižnoga fonda bila u uzlaznoj putanji. Usporedbe radi, pulska Gradska knjižnica (Biblioteca civica) 1912. imala je više od 8700 svezaka, a 1930. prilikom uključivanja u novonastalu Provincijsku knjižnicu (Biblioteca provinciale) 10.233 sveska. ${ }^{98} \mathrm{U}$ tom svjetlu podatak o 7000 (izgorjelih) svezaka u Narodnome domu možemo uzeti kao moguć.

Palež knjižnice Doma bit će tek uvertira u strahote fašizma i nacizma prema istom obrascu sljedećih desetljeća. Ostvarit će se time poruka židovskoga pjesnika, esejista i novinara Heinricha Heinea koji je 1821. u djelu Almansor napisao: „ondje gdje pale knjige, s vremenom će paliti i ljude“.

\section{Sudbina zgrade u Carrarinoj ulici br. 5: od Narodnoga doma do Case del fascio}

Od zgrade Narodnoga doma nakon požara 14./15. VII. 1920. ostali su samo goli zidovi (slika 3). Pulska mularija zalazila je do sredine kolovoza u ruševine Doma, igrajući se i skupljajući staro željezo koje je potom preprodavala. Dnevnik L'Azione upozorio je da bi moglo doći do nesreće, na što je reagirao Civilni komesarijat ogradivši ruine žicom uz natpis o zabranjenoj zoni. ${ }^{99}$ (Pod)stanari s drugoga i trećega kata, ${ }^{100}$ pak, gradskim su vlastima dopremili detaljne popise pokretnina koje su izgubili u požaru. Međutim, umjesto nadoknade štete dobili su simboličnu jednokratnu financijsku pomoć. Vlast je time dala do znanja da ne namjerava preuzeti odgovornost, ali da je voljna

97 „Za pučku knjižnicu u Puli“, Omnibus, 1124, 13. IV. 1909., 1; „Za javnu knjižnicu u Puli“, isto, 1136, 27. IV. 1909., 1; „Za Pučku Knjižnicu u Puli“, isto, 1141, 4. V. 1909., 1.

98 „Prva pučka zabava ak. Fer. Družtva 'Istra'“, Omnibus, 1079, 16. II. 1909, 1; „Pučka knjižnica u Pazinu“, Naša sloga, 49, 17. XII. 1914., 3; Bruno Dobrić, „Biblioteca provinciale dell'Istria“, Vijesti, glasilo Društva bibliotekara Istre, god . VIII, br. 9, 1989., 3, 10; Stipanov, Povijest knjižnica, 147; Tijana Barbić-Domazet i dr., Sveučilišna knjižnica Sveučilišta Jurja Dobrile u Puli, Pula 2019., 15.

99 „Sorveglianza?“, L'Azione, 188, 19. VIII. 1920., 2; „Incovenienti nell'edificio dell'ex Narodni Dom“, isto, 198, 31. VIII. 1920., 2; DAPA, CKP, kut. 17, 1920., f: C-12, br. 10625/1260, 26. VIII. 1920

100 Vratović u svojim zapisima navodi ukupno devet obitelji, od kojih tri talijanske narodnosti. Po njemu su jedino Talijani i dobili simboličnu donaciju. Civilni komesar obavijestio je talijansku Vladu - Središnji ured za nove provincije u Rimu o ukupno sedam obitelji, od kojih tri talijanske. HDA, Zemaljska vlada. Odjel za unutarnje poslove, Odsjek za Istru, br. 2905/1920., pismo dr. Mirka Vratovića upućeno Kraljevskoj hrvatsko-slavonskoj zemaljskoj vladi, povjereništvu za unutarnje poslove 29. VII. 1920.; DAPA, CKP, kut. 17, 1920., f: C-12, dopis Civilnoga komesarijata u Puli poslan u Rim 29. VII. 1920. 
donekle izraziti svoju karitativnu naklonost. ${ }^{101}$ Jedan bračni par - Giorgio i Caterina Indrigo - nije se mirio s načinom na koju su izgubili svoju stečevinu. Odlučili su poslati upit Ministarstvu unutarnjih poslova u Rimu vrlo ingeniozno postavljajući pitanja o tome tko je kriv za zločin, pritom sasvim precizno i jasno imenujući „fašiste“102. U tom pogledu isticali su kako „nije na njima da prepoznaju da je požar podmetnula mala jezgra fašista u suradnji i s potporom časnika i karabinjera - niti je na njima da prosvjetljuju Ministarstvo o radu vojnih vatrogasaca na gašenju požara"103. Potpisanoga Giorgia Indriga zanimalo je prije svega „ustanoviti činjenično stanje i prikazati svoju kritičnu i očajnu ekonomsku situaciju“. Kako je završio njegov zahtjev, nije nam poznato, ali je vjerojatno da je nakon dopisa satnika De Vite komesaru Oriolu, gdje je lakonski ustvrdio da je Indrigo nakon 18:30 mogao slobodno iznijeti svoje dragocjenosti ako je to želio, a uz to je „austrofil i opasni boljševički propagator“ (pericoloso propagandista bolsevico), ostalo mrtvo slovo na papiru. ${ }^{104}$ L'Azione je na svojim stranicama zanemario pitanje novih hrvatskih „beskućnika“, ali je izvijestio o teškoj sudbini mladoga bračnog para Zangrando, opisujući ih kao „nedužne u svakom pogledu“ i apelirajući na pomoć Grada i stanovništva. Drugim dvjema talijanskim obiteljima Mardessa i Indrigo posvetio je nešto manje pozornosti. ${ }^{105}$

Zamolbu za nadoknadu štete uputio je iz Subotice, gdje se smjestio s obitelji, i Lovro Škaljer. Pulskim gradskim vlastima objasnio je kako mu je u stanu i u uredu na drugome katu Narodnoga doma izgorio namještaj, roba, uredski spisi i knjige te je procijenio štetu na čak 300.000 lira. ${ }^{106}$ No, ni Škaljer, očekivano, nije imao u svojemu naumu više sreće od obitelji Indrigo.

101 DAPA, CKP, kut. 17, 1920., f: C-12, dopis Oriola Mosconiju 1. VIII. 1920. o financijskoj pomoći bivšim stanarima Narodnoga doma.

102 Prema svjedočanstvu Mirka Vratovića, na ulicu pred Domom bačeno je pokućstvo iz privatnih stanova, Posujilnice, Čitaonice, Gospodarske sveze, pisarne dr. Škaljera, Družbe Ćirila i Metoda. HDA, Zemaljska vlada. Odjel za unutarnje poslove, Odsjek za Istru, br. 2905/1920., pismo dr. Mirka Vratovića upućeno Kraljevskoj hrvatsko-slavonskoj zemaljskoj vladi, povjereništvu za unutarnje poslove 29. VII. 1920. Konzultacijom fotografskoga gradiva Povijesnoga i pomorskoga muzeja Istre - Museo storico e navale dell'Istria (vidi sliku 4), vidljivo je zgarište spaljenoga (dijela) inventara. Ovom prilikom zahvaljujem na stručnoj pomoći višoj kustosici Muzeja Lani Skuljan Bilić.

103 L'Azione je pisao kako su prosvjednici nastojali onemogućiti gašenje požara, a Vratović da su prisutni časnici, vojnici i fašisti prerezali vatrogasno crijevo, što je pridonijelo tome da zgrada, koja je mogla biti spašena, bude spaljena do temelja. „Violenta protesta di Pola contro l'assassinio di Spalato“, L'Azione, 158, 15 . VII. 1920., 1; HDA, ZV. OUP, OZI, br. 2905/1920., pismo dr. Mirka Vratovića o događajima u Puli od sredine do kraja srpnja 1920. Upućeno iz Ljubljane Kraljevskoj hrvatsko-slavonskoj zemaljskoj vladi, povjereništvu za unutarnje poslove u Zagrebu 29. VII. 1920.

104 DAPA, CKP, kut. 17, 1920., f: C-12, 26. VIII. 1920.; isto, br. 346/1, 19. XI. 1920.

105 „Vittime innocenti“, L'Azione, 160, 17. VII. 1920., 2; „Altre vittime innocenti“, isto, 162, 20. VII. 1920., 2. 106 DAPA, CKP, kut. 16, 1920., f: C-11. Dopis L. Škaljera, neadresiran (vjerojatno upućen pulskom civilnom komesaru), od 20. IX. 1920. 
Kakva je bila budućnost bivših hrvatskih kulturno-gospodarskih sjedišta pod fašizmom? Dok su u Rijeci prostori Hrvatske čitaonice 1925. prenamijenjeni za potrebe Jugoslavenskoga konzulata, u Narodnome domu u Pazinu iste je godine ustanovljen Fašistički dom - Casa del Fascio ${ }^{107}$ Sličnu sudbinu imat će i zgrada na pulskoj adresi Viale Carrara n. $5^{108}$. U nju su se, nakon nužne obnove, tijekom 1931. uselila tajništva fašističke organizacije Državnoga ureda (Aziende di Stato), Zavoda za zapošljavanje (Associazione fascista del pubblico impiego), Pošte i brzojava (A. naz. fascista postelegrafici), Željeznica (A. fas. ferrovieri) i Školstva (A. insegnanti fascisti-scuola primaria) te Ženski fasciji (Delegazione dei Fasci femminili). Na toj će adresi svoje mjesto pronaći i provincijsko sjedište Nacionalne fašističke stranke (Federazione provinciale del Partito Nazionale Fascista) i sjedište lokalnih sekcija organizacija Fašističke mladeži (Fascio Giovanile di Combattimento), kao i Fašističke sveučilišne mladeži (Gioventù Universitaria Fascista). ${ }^{109}$

\section{Zaključak}

Napad na pulski Narodni dom - hrvatski kulturni, gospodarski i politički centar, gotovo posve lišen mogućnosti djelovanja nakon talijanske okupacije studenoga 1918. - zbio se uvečer 14. VII. 1920. Bila je to prva organizirana akcija tek novoosnovanoga pulskoga Fascija di Combattimento, a po uzoru na fašističko nasilje u Trstu koje je kulminiralo paljenjem slovenskoga Narodnoga doma (Hotel Balkan) prethodnoga dana.

Konzultirani dokumenti zorno pokazuju da je napad bio planiran i insceniran te da su vojne i policijske snage aktivno sudjelovale u samome činu, što se nije moglo dogoditi bez placeta vicekvestora i civilnoga komesara kao najviših dužnosnika pulske civilne vlasti. Tiskani mediji stvarali su, uz potporu tih istih vlasti, atmosferu u kojoj se sve hrvatsko i slavensko predstavljalo kao opasnost za buduću aneksiju „talijanskih krajeva“ Kraljevini Italiji. Službena izvješća poslana iz pulskoga Civilnoga komesarijata generalnom komesarijatu u Trst te Vladi u Rimu opravdavala su incident u svjetlu spontanih

107 „L'inaugurazione della Casa del Fascio a Pisino“, L'Azione, 24, 28. I. 1925., 2; „Novi konzulat na Rijeci“, Pučki prijatelj, 15, 9. IV. 1925., 6.

108 Tijekom talijanske uprave dogodila se promjena ulične numeracije bivše zgrade Narodnoga doma. Dok je do 1918. bila na broju 4, u izvorima se od početka 30-ih godina 20. stoljeća pojavljuje na broju 5, a puno rjeđe na broju 4, što ostavlja (neuobičajenu) mogućnost da je zgrada imala dva broja (parni i neparni).

109 „Associazioni dei dipendenti del partito N. F.“, Corriere istriano, 80, 2. IV. 1931., 2; „I balli del G. U. F.“, isto, 247, 17. X. 1931., 3; „Per le Giovani fasciste“, isto, 248, 18. X. 1931., 3; „Comando Fascio Giovanile di Combattimento di Pola“, 255, 27. X. 1931., 2; ,Un appello dell’Ente Opere Assistenziali alla generosità dei cittadini“, isto, 277, 11. XI. 1931., 2; Guida generale di Trieste e della Giulia - 1932. X E. F., Trieste 1932., 359, Guida generale di Trieste e della Giulia - 1933 XI. E.F., Trieste 1933., 374. 
demonstracija kao posljedica ubojstava dvojice talijanskih vojnika u Splitu. Za počinjena nedjela, u kojima su u Carrarinoj ulici br. 5 do temelja stradali prostori Istarske posujilnice, gostionica, Javna i pučka knjižnica s Čitaonicom te više privatnih stanova i ureda, među kojima i onaj Lovre Škaljera, kao i za nedjela počinjena u noći 15./16. VII., kada su mete fašista i njihovih istomišljenika bili Klub socijalističke mladeži na Velom vrhu te stanovi odvjetnika Ive Zuccona i Mirka Vratovića, nitko sudski nije odgovarao niti je podignuta optužnica. Benito Mussolini otvoreno je priznao da je paljenje u Trstu i Puli bio čin koji su proveli fašisti. Unatoč pasivnosti talijanske Vlade u talijanskom parlamentu, socijalistički zastupnici tražili su istragu da bi se procesuirali odgovorni, no morali su se zadovoljiti već ustaljenim opravdavajućim narativom pulskoga komesara Oriola i vicekvestora Giuriata, čime će se slučaj prepustiti zaboravu. Takav će odnos provincijskih, regionalnih i (među) državnih vladajućih instanci spram nadirućega fašizma, posebice aktivnoga u Julijskoj krajini pa tako i u Istri, o kojem je potrebno dopuniti dosadašnje historiografske spoznaje, omogućiti zametak društveno-političkoga obrata i pokrenuti novi val nasilja koji će u konačnici dovesti fašiste na vlast, kako na istarskom poluotoku, tako i u Kraljevini Italiji.

\section{Sažetak}

U radu se kroz konzultaciju arhivskoga i novinskoga gradiva razmatraju i analiziraju politička zbivanja na istočnoj obali Jadrana koja su kulminirala fašističkim paljenjem tršćanskoga (13. VII. 1920.) i pulskoga (14. VII. 1920.) Narodnoga doma te napadom na pulski Klub socijalističke mladeži i odvjetničke urede Mirka Vratovića i Ive Zuccona (16. VII. 1920.). Fokus rada je, nakon kraćega povijesnoga pregleda djelovanja Narodnoga doma, posebno usmjeren rekonstrukciji tih pulskih incidenata, uloge fašista u neredima, pozicioniranju lokalnih civilnih vlasti (civilnoga komesara i vicekvestora tijekom i nakon nasilne epizode), medijskom diskursu (agitaciji istarskih novina, kao i onih s prostora Kraljevine Italije) te, u konačnici, reakciji talijanskih parlamentaraca socijalista. Blaga reakcija pa i direktno sudjelovanje pripadnika službi javnoga reda i mira te vojske u neredima, nevjerodostojni izvještaji lokalnih civilnih vlasti i tiskanih medija o pitanju involviranosti osoba, kao i samoga tijeka napada, jasno su naznačili politiku negiranja prava na očuvanje hrvatske kulture i nacionalnoga identiteta uopće. Paljenjem Dom(ov)a, čime se u svom govoru u pulskom kazalištu pohvalio i sam Benito Mussolini (21. IX. 1920.), uništeno je kulturno, gospodarsko i političko, tada već simbolično, sjedište pulskih Hrvata, a spaljivanjem više tisuća knjiga tamošnje Javne pučke knjižnice počinjen je kulturocid, koji će 
u povijesti ostati zapisan kao jedna od prvih fašističkih lomača u Europi. Time je jasno naznačena politika koja će se u Istri početi provoditi i prije službena dolaska na vlast fašista u listopadu 1922., prvenstveno u pogledu nasilne asimilacije tzv. „inorodaca” (Hrvata i Slovenaca).

\section{L'incendio del Narodni dom di Pola del 14 luglio 1920 ovvero com'è stata aperta la scatola di Pandora del periodo fascista}

\section{Riassunto}

Basato sulle consultazioni di materiale d'archivio e giornalistico, il contributo tratta ed analizza gli avvenimenti politici svoltisi sulla costa orientale dell'Istria che culminarono con l'incendio dei Narodni dom di Trieste (13 luglio 1920) e Pola (14 luglio 1920) e con l'attacco al Club della gioventù socialista di Pola e agli studi legali di Mirko Vratović e Ivo Zuccon (16 luglio 1920). Dopo una breve rassegna sull'attività del Narodni dom, il contributo si concentra in particolar modo sulla ricostruzione degli incidenti che hanno avuto luogo a Pola, sul ruolo che i fascisti ebbero nel contesto dei disordini, sulla posizione adottata delle autorità civili locali (dal commissario civile e dal vicequestore durante e dopo gli episodi di violenza), sul discorso mediatico (l'agitazione da parte della stampa istriana e di quella del territorio del Regno d'Italia) e, infine, sulla reazione dimostrata dai parlamentari italiani socialisti. La reazione blanda e la partecipazione diretta dei membri dei servizi dell'ordine pubblico e militare ai disordini, i rapporti inattendibili delle autorità civili locali e della stampa riferiti al coinvolgimento delle persone e allo svolgimento dell'attacco erano un indice chiaro della piega che la politica stava prendendo verso il negazionismo del diritto alla conservazione della cultura croata e dell'identità nazionale in genere. L'incendio del Narodni dom (ovvero dei due Narodni dom), impresa vantata anche dallo stesso Benito Mussolini durante il suo discorso tenutosi al teatro di Pola (21 settembre 1920), distrusse la sede culturale, economica e politica, in quel periodo ormai soltanto simbolica, dei croati mentre con il rogo di alcune migliaia di libri della Biblioteca popolare pubblica situata presso il Narodni dom venne commesso un culturicidio, un avvenimento che rimarrà segnato nella storia come uno dei primi roghi fascisti in Europa. Tali avvenimenti annunciarono chiaramente il tipo di politica che sarebbe stato messo in atto in Istria anche prima dell'ascesa ufficiale al potere dei fascisti nell'ottobre 1922, in special modo sotto l'aspetto dell'assimilazione violenta dei cosiddetti "allogeni" (croati e sloveni).

\section{The arson of People's Hall in Pula on 14 July 1920, or how the fascist Pandora's Box was opened}

\section{Abstract}

The paper discusses and analyses political events on the eastern Adriatic coast, culminating in the fascist arson of the People's Halls in Trieste (13 July 1920) and Pula (14 July 1920), as well as the attack on the Socialist Youth Club of Pula and law firm offices of Mirko Vratović and Ivo Zuccon (16 July 1920), by consulting the archival and newspaper material. The focus of the paper, after a brief historical overview of the People's Hall, is specifically centred around the reconstruction of these inci- 
dents in Pula, the role of fascists in the riots, the positioning of local civilian authorities (civilian commissioner and vice-quaestor during and after the violent episode), media discourse (the agitation stemming from the Istrian newspapers, as well as those from the territory of the Kingdom of Italy) and, ultimately, the reaction of the Italian Socialist parliamentarians. Mild reaction and direct participation of the members of the public order and peace services, as well as the army, in the riots, unreliable reports of local civilian authorities and printed media on the involvement of persons, as well as the course of the attack, clearly indicated the policy of denying the right to preserve Croatian culture and the national identity in general. The arson of the Hall(s), which Benito Mussolini himself boasted about in his speech at the Theatre in Pula (21 September 1920), destroyed the cultural, economic and political, already symbolic by then, seat of the Croats in Pula, and with the burning of thousands of books belonging to the Public People's Library, a culturicide was committed there, which will go down in history as one of the first fascist bonfires in Europe. This clearly indicates the policy that will be implemented in Istria even before the official fascists' rise to power in October 1922, primarily in terms of violent assimilation of the so-called "native foreigners" (Croats and Slovenes). 


\section{Prilozi}

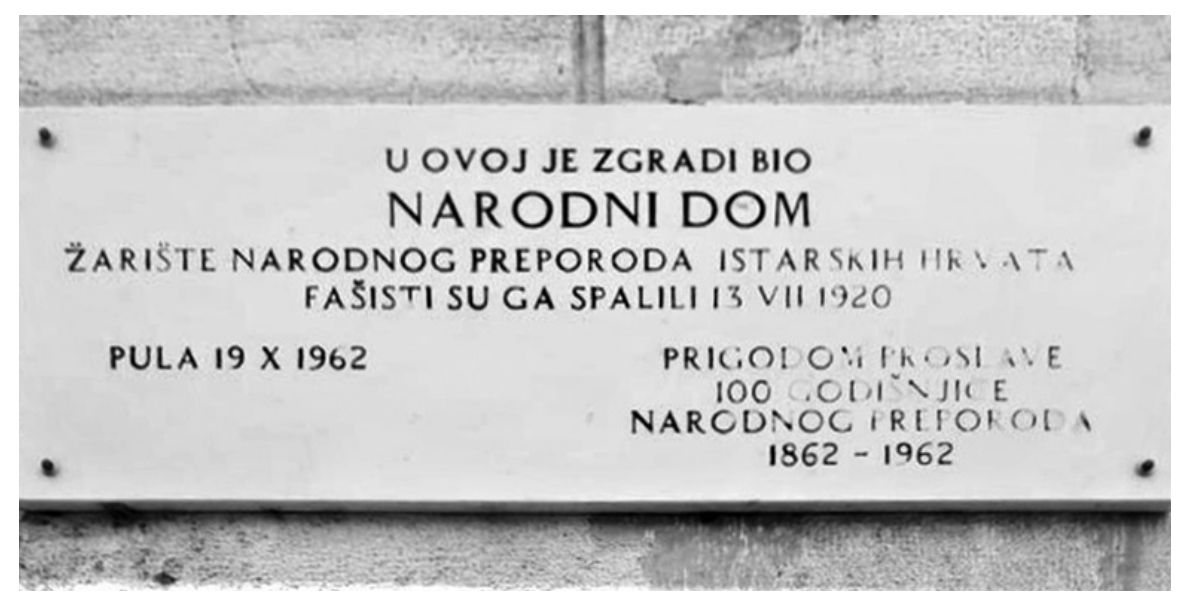

Sl. 1. I danas na spomen-ploči na zgradi stoji pogrešan podatak o datumu paljenja Narodnoga doma

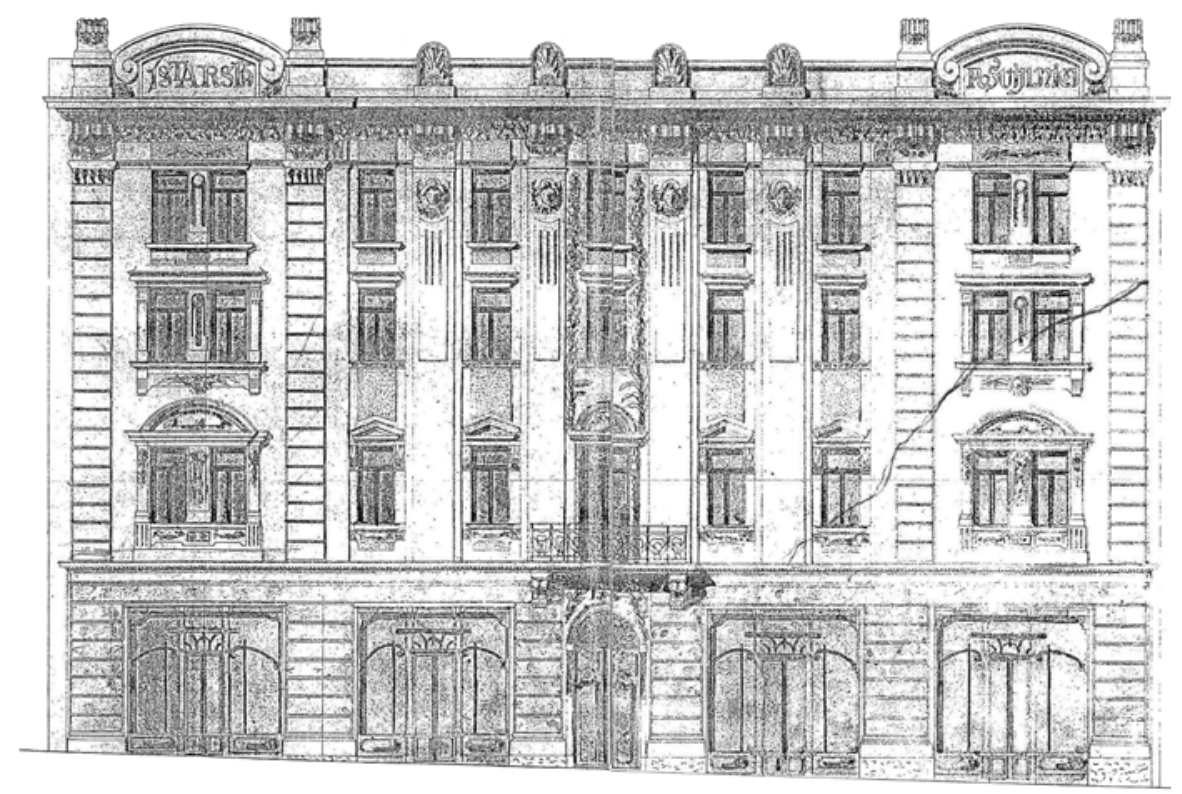

Sl. 2. Skica pročelja Narodnoga doma (Iz arhive Županijske komore Pula - Hrvatske gospodarske komore) 


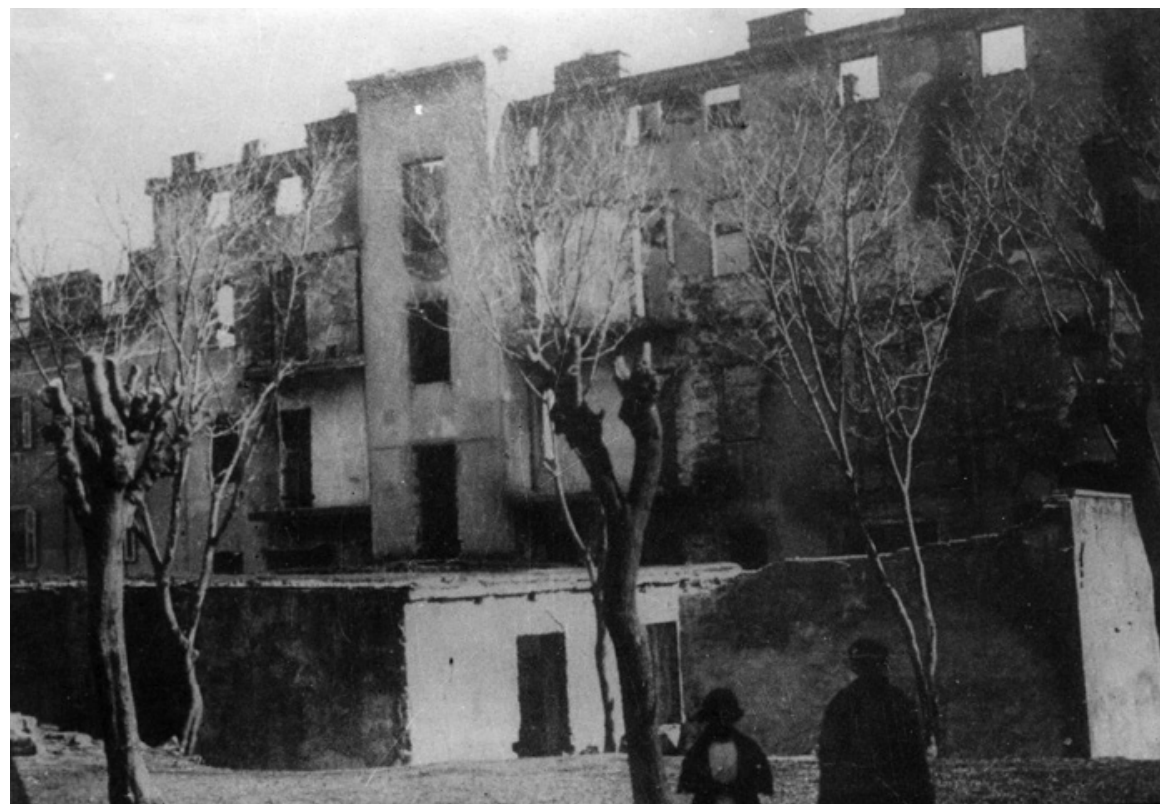

Sl. 3. Stražnja strana spaljenoga Narodnog doma (Povijesni i pomorski muzej Istre - Museo storico e navale dell'Istria, F-2327)

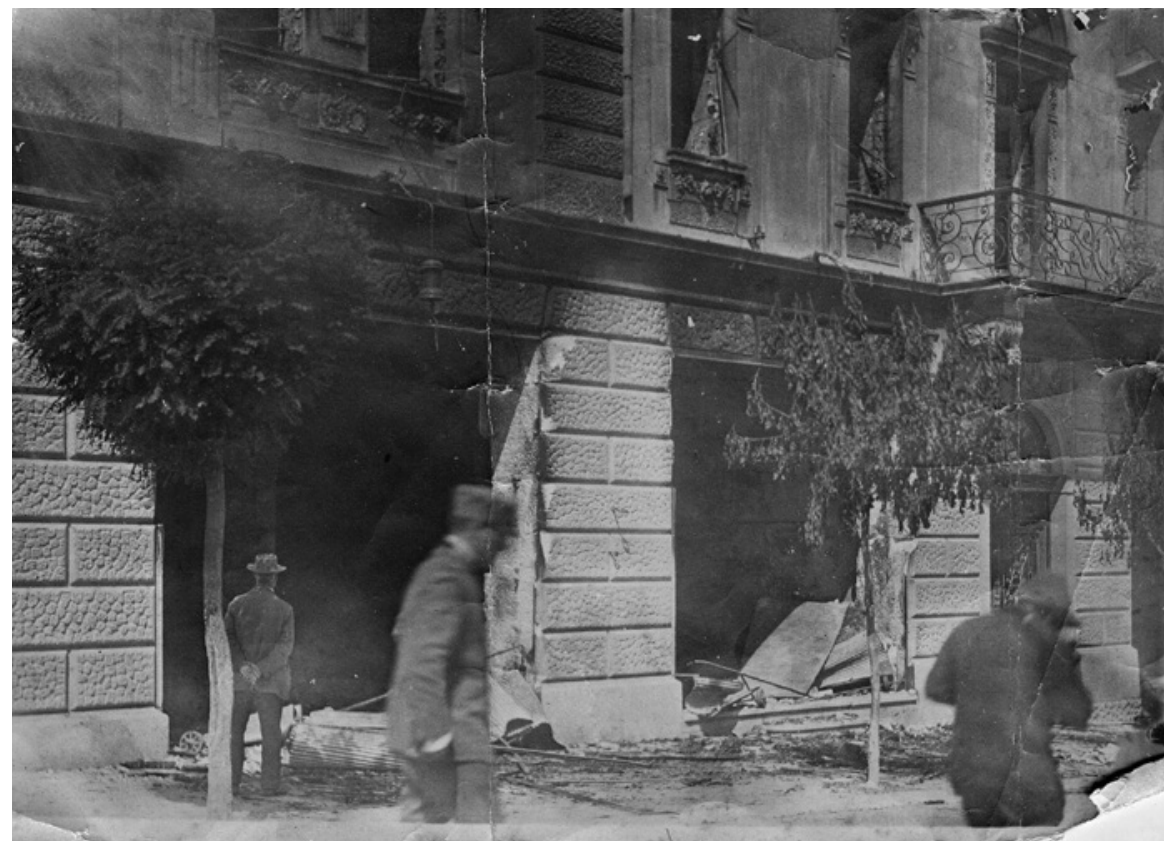

Sl. 4. Vidljivi tragovi zgarišta pred Narodnim domom (Povijesni i pomorski muzej Istre - Museo storico e navale dell'Istria, F-2318) 